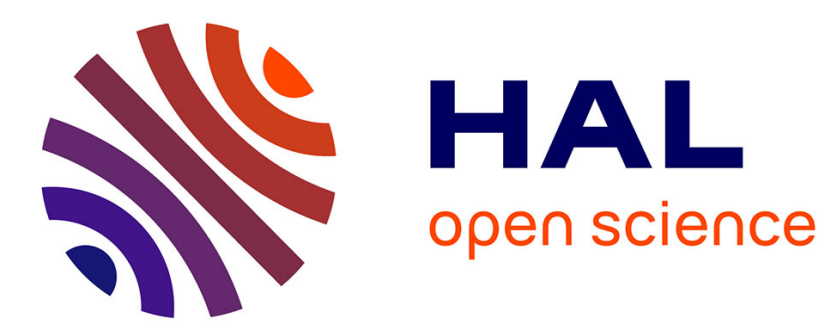

\title{
The Switch from Continuous to Call Auction Trading in Response to a Large Intraday Price Movement \\ Juan C Reboredo
}

\section{To cite this version:}

Juan C Reboredo. The Switch from Continuous to Call Auction Trading in Response to a Large Intraday Price Movement. Applied Economics, 2011, pp.1. 10.1080/00036846.2010.526584 . hal00667598

\section{HAL Id: hal-00667598 \\ https://hal.science/hal-00667598}

Submitted on 8 Feb 2012

HAL is a multi-disciplinary open access archive for the deposit and dissemination of scientific research documents, whether they are published or not. The documents may come from teaching and research institutions in France or abroad, or from public or private research centers.
L'archive ouverte pluridisciplinaire HAL, est destinée au dépôt et à la diffusion de documents scientifiques de niveau recherche, publiés ou non, émanant des établissements d'enseignement et de recherche français ou étrangers, des laboratoires publics ou privés. 


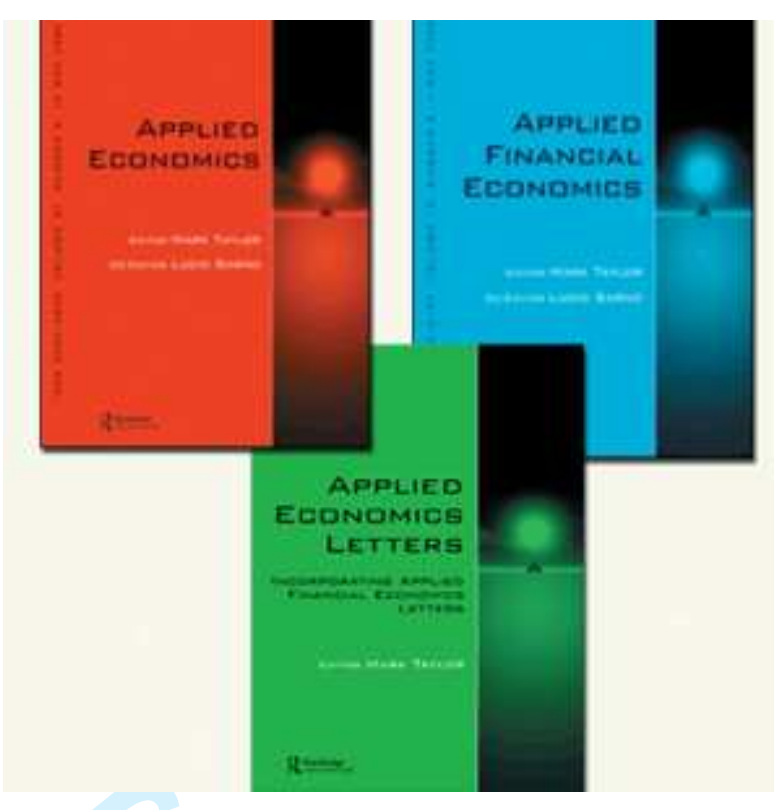

\section{The Switch from Continuous to Call Auction Trading in Response to a Large Intraday Price Movement}

\begin{tabular}{|c|c|}
\hline Journal: & Applied Economics \\
\hline Manuscript ID: & APE-2009-0357.R1 \\
\hline Journal Selection: & Applied Economics \\
\hline $\begin{array}{r}\text { Date Submitted by the } \\
\text { Author: }\end{array}$ & $15-J u l-2010$ \\
\hline Complete List of Authors: & $\begin{array}{l}\text { Reboredo, Juan; Universidade de Santiago de Compostela, } \\
\text { Departamento de Fundamentos del Analisis Economics }\end{array}$ \\
\hline JEL Code: & $\begin{array}{l}\text { G10 - General < G1 - General Financial Markets < G - Financial } \\
\text { Economics }\end{array}$ \\
\hline Keywords: & $\begin{array}{l}\text { price volatility, Call auction trading, price discovery, volatility } \\
\text { auctions }\end{array}$ \\
\hline
\end{tabular}

\section{scholarONE" \\ Manuscript Central}




\title{
The Switch from Continuous to Call Auction Trading in Response to a
}

\section{Large Intraday Price Movement}

\author{
Juan C. Reboredo* \\ Universidad de Santiago de Compostela, Spain \\ e-mail: juancarlos.reboredo@usc.es \\ Phone: +34981563100 ext. 11675
}

This version: July 2010

\footnotetext{
* I am especially indebted to Ian-Charles Coleman for his constructive criticism and corrections. I also thank Lluís Brú, José M. Ortiz Repiso, José A. Pérez, Roberto Pascual, Mikel Tapia, and seminar participants at the Universidad Carlos III (Madrid), the Bolsa de Madrid, the Simposio de Análisis Económico 2004 and the Foro de Finanzas 2004 for their constructive comments on previous versions of this paper, circulated under the title "The Switch from Continuous to Periodic trading as a circuit breaker. Evidence from the Spanish Stock Market". I thank the Spanish Stock Exchange for providing the database, and Rafael Villar for research assistance. I am very grateful for partial financial support from the Spanish Stock Exchange in the form of the Best Research Paper on Stock Markets Prize (2004). I am also grateful for financial support from the Center for Economic and Financial Research (CIEF) of the Caixa Galicia Foundation, from the Xunta de Galicia (under contract PGIDIT06PXIB201002PR and INCITE09201042PR), and from research grant MTM2008-03010. Address for correspondence: Juan C. Reboredo, Department of Economics, Universidad de Santiago de Compostela, Avda. Xoán XXIII, s/n., 15782 Santiago de Compostela, SPAIN. Phone: +34 881811675, e-mail: juancarlos.reboredo@usc.es.
} 


\title{
The Switch from Continuous to Call Auction Trading in Response to a Large Intraday Price Movement
}

\begin{abstract}
Some European exchanges (e.g. Euronext, Frankfurt and Madrid) make use of a mechanism to moderate price volatility that was proposed by Madhavan (1992, Journal of Finance, 47(2) 607-641) as preferable to a trading halt in times of market stress. It consists of a temporary switch from continuous to call auction trading in an individual security whenever its price moves beyond predetermined limits. This paper studies whether this mechanism sharpens the information content of prices, dampens volatility, and normalizes trading volume and intensity. Taking intraday data for the Madrid order-driven continuous market, I find post-switch improvements in the information content of prices and reductions in volatility, especially for thinly traded stocks. Trading volume and intensity peaked around auctions, but soon returned to pre-event levels.
\end{abstract}

\section{JEL Classification: G1}

Keywords: Call auction trading, price discovery, price volatility, volatility auctions 


\section{Introduction}

Most stock exchanges around the world, and all continuous trading systems, make use of market control mechanisms devised to moderate excessive price volatility, allow the fair distribution of information to all market participants, and maintain an orderly market. ${ }^{1}$ Informational asymmetries and/or diversity of opinion can be pronounced with the arrival of new information in the market, or even when there is a marked imbalance between supply and demand. The most widespread control mechanism is a temporary halt in trading of an individual stock, which can be triggered discretionally by a supervisory committee in response to the stock's market conditions (e.g. violation of exchange rules, rumour, news releases or order imbalance), or automatically whenever an attempt is made to trade the stock at a price outside a pre-determined percentage or point variation from the previous day's close. ${ }^{2}$ The former approach is employed by the New York Stock Exchange (NYSE) and Nasdaq, the latter by Tokyo, Taiwan and US futures markets.

The effects of suspending trade in individual stocks, however the trading halt is triggered, have been extensively discussed in the literature. Greenwald and Stein $(1988,1991)$ argue that, in a continuous trading system, an abnormal increase in price volatility discourages traders from participating in the market, and that trading halts should restore normality by facilitating price discovery. In keeping with this hypothesis, Corwin and Lipson (2000) found that during NYSE trading halts investors adjust their positions by submission and cancellation of orders. Similarly, Edelen and Gervais (2003) found that trading halts, which were preceded by increased informational asymmetry between the exchange and specialists regarding the quoted price schedule, reduced agency costs associated with the organization of the exchange market. Kodres and O'Brien (1994) argue that imposing limits on price movements can reduce investment risk, since in times of marked

\footnotetext{
${ }^{1}$ See Galper (1999)

${ }^{2}$ For reviews of the trading halt literature see Kyle (1988), France et al. (1994), Harris (1998), and Kim and Yang (2004).
} 
price volatility the capacity of investors for prompt adjustment of their trading activity to rapidly changing situations and new information may prove insufficient because of technological or cost limitations.

However, unfavourable effects of trading halts have also been pointed to. Brown and Jennings (1989) and Grundy and McNichols (1989) reported that, according to the predictions of learningthrough-trading models, trade suspension leads to inefficient price discovery and relatively noisy prices, traders being unwilling to reveal their demand completely in the absence of recent transaction prices. Subrahmanyam (1994) also suggested that trading halts may have undesirable effects on volatility and market liquidity. These theoretical considerations are supported by reports that both volatility and volume have risen to unusually high levels following NYSE trading halts (Lee, Ready and Seguin 1994; Fong 1996; Corwin and Lipson 2000), and that intraday Nasdaq trading halts have similarly been followed by the maintenance of unusually high levels of volatility and inside bid-ask spread for around half an hour or more (Christie, Corwin and Harris 2002). These effects of intraday trading halts are furthermore coherent with reports that, on the interday time scale, opening prices are, in spite of opening auctions, noisier than prices negotiated later in the day (Amihud and Mendelson 1987, 1991; Stoll and Whaley 1990; Gerety and Mulherin 1994).

As an alternative to temporary trading halts, some European stock markets, including Frankfurt, Paris, Madrid, Euronext, the European Energy Exchange and the Irish Stock Exchange, respond to unusually large price jumps during trading by temporarily switching from continuous trading to a call auction that ends with the aggregation of trades at a predetermined point in time. The use of this kind of mechanism was first recommended by Madhavan (1992) on the basis of theoretical results suggesting that in times of market stress a periodic trading system enhances price discovery and is less susceptible to collapse than a continuous trading system, although Madhavan proposed that the switch from continuous to call auction trading be triggered by the bid-ask spread 
rather than price jumps. There are several potentially important differences between the temporary auction and the temporary trading halt. First, unlike trading halts, auctions do not suspend trading altogether, and should thus avoid delay in price discovery in circumstances in which sufficient information is available but is initially unevenly distributed. Second, discretionary trading halts can be imposed in anticipation of relevant news before prices become jumpy; indeed, most NYSE trading halts occur before news events (Lee, Ready and Seguin 1994; Corwin and Lipson 2000), whereas temporary auctions seem often to occur as a result of price jumps following news events (see Section 3 below). Third, the switch to auction trading is rule-based and is therefore predictable. Fourth, the duration of temporary auctions is fixed and much shorter than that of trading halts (between 5 and $5 \frac{1}{2}$ minutes in Madrid), which is likely to affect the behaviour of investors both during and following the call auction. Related to this, fifth, the temporary auction does not limit the daily movement of prices, at least in Madrid, where the price limits triggering it are updated when it ends. Notwithstanding, it should be borne in mind that some of these differences can be blurred in mixed systems; on the NYSE, for example, call auctions are held at the end of trading halts before continuous trading recommences.

Theoretical studies suggest that, relative to continuous trading systems, pure call auction systems enhance price discovery (Economides and Schwartz 1995; Handa and Schwartz 1996), reduce volatility (as order arrival time does not affect prices) (Schwartz 2001), and in conditions of informational asymmetry result in liquidity traders incurring lower adverse selection costs (Kyle 1985; Pagano and Röell 1996). These predictions are supported by the results of simulations (Schnitzlein 1996; Theissen 2000). Empirically, call auctions have been found to be efficient price discovery mechanisms by Amihud and Mendelson (1991), Stoll and Whaley (1990), Amihud, Mendelson and Murgia (1990), and Pagano and Schwartz (2003). However, there has been little empirical evidence concerning the effectiveness of temporary call auction trading as a mechanism to 
control a primarily continuous market. The validity of the above results in this situation is in practice not immediately obvious, because price-triggered temporary call auctions are often "blind", i.e. they are conducted without letting traders see other orders or the evolution of the market-clearing price, so forcing them to obtain information from outside the order book.

This paper examines empirically the impact of the switch to call auction trading on market quality for stocks traded on the Spanish Stock Exchange (SSE), a computerized, order-driven continuous market in which attempted sharp price movements trigger short, blind call auctions termed "volatility auctions". Specifically, I study a series of 543 such auctions to determine whether this mechanism delays or favours price discovery, whether it exacerbates or dampens volatility and bid-ask spread, and whether it affects trading volume and intensity. To this end I compare the data for these auctions with those of a series of reference events in which a price movement approached the auction-triggering limit but did not quite reach it. I find evidence that pre-auction continuous trading prices are biased estimators of the value of the security, whereas the auction and post-auction prices of less-liquid stocks show no statistically significant bias and, like those of more-liquid stocks, are more stable than those of reference events. In keeping with this result, I find that the volatility of stocks as measured by absolute price changes and price standard deviation is significantly more depressed after call auctions than after reference events (which contrasts with the persistent high levels of volatility reported to follow trading halts on the NYSE (Lee, Ready, and Seguin 1994; Fong 1996; Corwin and Lipson 2000), intraday trading halts on Nasdaq (Christie, Corwin, and Harris 2002), and the execution of price limits on the Tokyo exchange (Kim and Rhee 1997). The finding that bid-ask spread is unusually wide in the minutes immediately preceding a volatility auction but not in the minutes preceding reference events suggests that triggering volatility auctions by price is more or less equivalent to triggering them by bid-ask spread, as originally proposed by Madhavan (1992). Finally, share trading volume and the number of transactions, which tend to increase rapidly 


\section{SSE operational details}

The SSE is a computerized, order-driven continuous market in which liquidity is provided by an open limit order book. The market operates ${ }^{3}$ from 08:30 to 17:35 hours, Monday to Friday, opening with a half-hour call auction during which orders can be placed, modified or cancelled but not executed. Three types of orders are permitted: market orders, which are dealt with by walking up or down the book until totally executed; limit orders, which are executed by walking the order book subject to the specified limit, any unexecuted remnant being left on the order book with the same limit; and best price orders, which are executed at the best price available when placed, any unexecuted remnant being left on the order book with that price as limit. During the opening call auction the order book is not made public to market participants, but for each stock the marketclearing price (the price at which trading volume would be greatest) ${ }^{4}$ is updated and publicized in real time together with the associated virtual trading volume. The auction terminates at a random instant within a 30-second period, after which orders are matched at the current market-clearing prices (which are taken as the day's opening prices) and continuous trading commences, all orders

\footnotetext{
3 For a more detailed account of the SSE trading system and trading rules, visit http://www.sbolsas.es.

${ }^{4}$ The official rules provide for resolution of possible ties between different prices.
} 
received during the auction that have not been executed remaining on the order book. Trading during the opening auction amounts to about $3 \%$ of total daily trade.

During the continuous trading regime, which prioritizes orders primarily by price and secondarily by submission time (as, for example, at Frankfurt, Paris, Toronto and Tokyo), the five best positions of the order book on either side are accessible to market participants. Except for the 5-minute volatility auctions mentioned in the Introduction and described in detail below, continuous trading proceeds until 17:30 hours, when the day's closing prices are established by a 5-minute call auction similar to the opening auction (and likewise terminated at random within a period of 30 seconds).

Volatility auctions replaced price limits as a market control mechanism on 14 May 2001, as part of the harmonization of trading systems in Europe. According to the Spanish Market Control Commission, their purpose is to ensure that significant price fluctuations only occur with the involvement of a large number of market participants. Accordingly, they are designed to give market participants time to digest information without closing down trade altogether. They are triggered whenever an attempt is made to trade a security at a price outside either of two publicly assigned price ranges (hereinafter "price collars"). The "dynamic" price collar of a stock is centred on the price of the latest trade, and its width $(1 \%, 1.5 \%, 2 \%, 2.5 \%, 3 \%, 3.5 \%, 4 \%$ or $8 \%$ of that price) is revised every six months on the basis of the history of intraday price fluctuations of the stock. This collar prevents large intraday discontinuities in price. The "static" price collar is centred on the price arising from the latest call auction (be it the opening auction or a volatility auction), and its width $(4 \%, 5 \%, 6 \%, 7 \%, 8 \%$ or $10 \%$ of that price) is likewise revised every six months, but on the basis of the history of day-to-day price fluctuations. This collar thus limits price movements relative to the 
last auction-mediated consensus. By construction, the static price collar is always wider than the dynamic collar. ${ }^{5}$

Volatility auctions last 5 minutes plus the usual random end period of up to 30 seconds. During the auction traders can submit, cancel or modify orders, but no trade is executed, and traders do not have access to the order book, the current virtual market-clearing price, or the trading volume. They thus receive no feedback on the impact of their orders on price, a provision which, together with the short duration of the auction, is intended to minimize the temptation to try to distort the information content of the resolution price by submitting fake orders that are later withdrawn. At the end of the volatility auction, orders are matched at the consensus market-clearing price, the collars are updated, and continuous trading resumes.

\section{Data}

I studied 543 volatility auctions that occurred between May 2001 and January 2002. Since the intraday pre-auction and post-auction behaviour of these stocks were to be examined, only auctions preceded and followed by 30 minutes' uninterrupted continuous trading were considered (in particular, all auctions considered occurred between 09:30 and 17:00 hours). For each auction, the following information was obtained: its date; the times (to the second) of its commencement and termination; the resulting consensus price and associated trade volume; the opening and closing prices of the stock concerned on that day; and the bid and ask prices, transaction prices and volumes, and static and dynamic collars of the stock in the half-hours preceding and following the auction.

\footnotetext{
${ }^{5}$ The static and dynamic price collars are also used to control opening and closing auctions. When the final virtual resolution price of the auction lies outside one of the collars (the static collar in the case of opening auctions, and either the static or the dynamic collar in that of closing auctions), the auction is extended for 2 minutes. However, no such extension of volatility auctions is possible.
} 
For each volatility auction, two sets of analogous reference data were assembled for the purposes of comparison. One, intended to capture the normal trading behaviour of the stock involved (and hereinafter referred to as the "normal reference set"), consisted of data for it for the same 65-minute periods of the 10 days preceding and the 10 days following the day of the auction. The other comprised data for that occasion, within the same month as the auction, on which the price of the stock had most nearly breached one of its collars without actually doing so (in case of ties, the occasion that was closest to the auction in date and time of day was used). For the sake of brevity, in most of this paper only results obtained using this second, "volatile" reference sample are presented; results obtained with the normal reference sample (available upon request) lead to conclusions consistent with those based on the volatile reference sample. All data were provided by the Market Control Commission of the SSE.

To characterize the volatility auctions in terms of the causes of the volatility triggering them, four kinds of cause were considered: uncertainty prior to the announcement of firm-specific news (the commonest cause of trading halts on the NYSE (Lee, Ready and Seguin 1994; Corwin and Lipson 2000); uncertainty in the wake of "official" firm-specific news announced by the Spanish stock market regulatory body, the National Stock market Commission; uncertainty in the wake of other publicly announced firm-specific news; and uncertainty of a market-wide nature, such as might be generated by macroeconomic announcements. About $50 \%$ of auctions were classified as due to market-wide uncertainty because they occurred on the same day as, or on the day following, news of macroeconomic relevance; most of these auctions occurred in September 2001 in the aftermath of the attack on the Twin Towers (see Fig. 1A). Another $40 \%$ of auctions were regarded as due to uncertainty following "unofficial" firm-specific news because they occurred on the same day as, or the day following, the appearance of a relevant announcement in at least one of the two major Spanish financial newspapers. A much smaller number of auctions, $6 \%$, were classified as due to 
uncertainty generated by "official" firm-specific news because they occurred on the same day as an announcement concerning the firm in question by the National Stockmarket Commission; and only $0.2 \%$ were attributed to pending news because they occurred on the day before a firm-specific National Stockmarket Commission announcement. Finally, about $4 \%$ of auctions satisfied none of the above criteria; the attempted price movements triggering these auctions may have been due to order imbalance, large uninformed orders, or even typing mistakes. We assume that the distribution of reference events by apparent cause is similar to that of the auctions.

Most of the stocks involved in volatility auctions (63\%) were not contributors to IBEX-35, the market index based on the most actively traded SSE stocks. Some 58\% of auctions were triggered by attempted excursion outside the static price collar, and $42 \%$ by attempted excursion outside the dynamic price collar. There were greater numbers of auctions on Monday and Friday than on mid-week days (Fig. 1B), which may be attributed to the effect of weekend stock return variations, and proportionately more auctions in the first half-hour or so following 09:30, i.e. during the post-opening peak in market activity, than at other times of day (Fig. 1C).

\section{[INSERT FIGURE 1 HERE]}

To investigate whether pre- and/or post-auction stock behaviour might depend on various characteristics of the stocks or market circumstances, analyses were performed both for the whole sample and for various subsamples. Specifically, the subsamples considered were auctions involving IBEX-35 stocks, to investigate the influence of liquidity; auctions occurring in September and October 2001, to investigate the influence of general market volatility, the market having been especially volatile in the aftermath of the Twin Towers attack; morning, early afternoon and late 


\section{Methods and Results}

\subsection{Price Discovery}

To analyse whether volatility auctions facilitate price discovery, in this section I examine prices $P_{t}$ before and after auctions and reference events. ${ }^{7}$ Specifically, I examine the last price in successive 5-minute intervals measured backwards from the time of the auction start or reference event $(t=-6, \ldots,-1)$ and forward from the resumption of continuous trading or reference event $(t=1, \ldots, 6)$ (in the case of auctions, the re-opening price is also considered). Like Biais, Hillion, and Spatt (1999) in their study of price discovery and learning during the opening call auction on the Paris Bourse, I identify the equilibrium price to be discovered on day $T$ with the closing price $\left(P_{T}\right)$, take

\footnotetext{
${ }^{6}$ Parallel analyses were also carried out for subsamples defined by whether the auction-resolving price was higher or lower than the price in the last transaction before the auction. No asymmetry was found between these two subsamples as regards the behaviour of price discovery, price volatility, bid-ask spread or trading volume and intensity (results available on request).

${ }^{7}$ Unfortunately it has not been possible to gain access to data allowing analysis of the progress of learning during volatility auctions.
} 
the previous day's closing price $\left(P_{T-1}\right)$ as a proxy for the pre-session expectation of the equilibrium price, and consider returns from the previous close rather than raw prices so as to correct for heteroscedasticity. I first examine, for each $t$, whether the approximate return from the previous close, $\quad x_{t}=\ln \left(P_{t} / P_{T-1}\right)$ differed significantly from the approximate close-to-close return $x_{T}=\ln \left(P_{T} / P_{T-1}\right)$, to which end I apply the signed-rank test to the set of 543 return ratios $y_{i, t}=x_{i, t} / x_{i, T}$ $(i=1, \ldots 543)$ for the null hypothesis

$$
\mathrm{H}_{0}: M_{t}=1 \text {, }
$$

where $M_{t}$ is the population median return ratio at time $t$. If the call auction leads to price discovery, $\mathrm{H}_{0}$ should not be rejected for $t \geq 0$, but might be for $t<0$. Even if $\mathrm{H}_{0}$ were rejected for all $t$, a degree of price discovery would be indicated by the estimate of $M_{t}$ being significantly closer to unity for $t \geq 0$ than for $t<0$. If $\mathrm{H}_{0}$ were rejected for $t \geq 0$ but not for $t<0$, the inference would be that the call auction distorts price discovery.

Figure 2, which plots the sample medians of the $y_{i, t}$, shows that return ratios $y_{i, t}$ generally underwent a substantial increase as a result of the volatility auction, which suggests that the auction led to price learning. Furthermore, return ratios remained stable and close to unity in the half-hour following the auction, showing the continued validity of what had been learnt. By contrast, they differed appreciably from unity during most of the half-hour preceding the auction, though they did tend to rise towards the end of this period. The signed rank test results listed in Column 2 of Table 2 (Panel A) endorse these observations, $\mathrm{H}_{0}$ (eq. 1) being rejected at all times prior to the switch but not in the quarter-hour following the resumption of trading (and although $\mathrm{H}_{0}$ is rejected between 20 and 30 minutes after resumption, absolute $z$ values remain smaller than before the switch). Panels B and $\mathrm{C}$ of Column 2 confirm that return ratio medians differed significantly in all before-after comparisons (including comparison of mean-over-time pre-auction $y_{i, t}$ with mean-over-time postresumption $y_{i, t}$; see Panel $\mathrm{C}$ ), and also during the pre-auction period, but not during the post- 
resumption period.

\section{[INSERT FIGURE 2 HERE]}

\section{[INSERT TABLE 2 HERE]}

As was noted in the previous section, most of the volatility auctions in the sample occurred following the announcement of macroeconomic or firm-specific news. The pre- and post-auction behaviour pattern described above suggests that, in general, the new information was successfully incorporated into prices by the end of the auction. However, since price discovery actually appears to have begun before the auction (see Fig. 2), the question arises whether it would have been just as efficient, or perhaps even more so, in the absence of the latter. Analysis of the data for reference events (Table 3) shows: 1) that return ratios half-an-hour before the event were significantly less than unity but greater than half-an-hour before auctions; 2) that during the half-hour preceding the event return ratios rose steadily to nearly unity (whereas pre-auction return ratios rose to a median value of 0.84 ); and 3) that during the following half-hour return ratios remained close to unity on average, but fluctuated much more than after auctions. This behaviour suggests that larger, auctiontriggering price jumps occurred in the final phases of a faster, accelerating process of information assimilation, and that although auctions certainly did not interrupt this process, their chief effect was to dampen subsequent uncertainty.

\section{[INSERT TABLE 3 HERE]}

As a rather different test of the existence of price discovery, I also performed a regression analysis based on the same assumption as was made by Biais, Hillion, and Spatt (1999), namely, that if intraday prices $P_{t}$ are unbiased estimates of $P_{T}$, then the return $\left(P_{, t}-P_{T-1}\right) / P_{T-1}$ should correlate with the close-to-close return $\left(P_{T}-P_{T-1}\right) / P_{T-1}$, with slope one. Accordingly, the auction panel data were fitted with the regression model 


$$
y_{i, t}=D_{t}\left(\alpha+\sum_{t=-5}^{-1} \beta_{t} \delta_{t}\right)+\left(1-D_{t}\right)\left(\omega+\sum_{t=1}^{6} \beta_{t} \delta_{t}\right)+\varepsilon_{i, t}
$$

where $i$ denotes the switch event ( $i=1, \ldots 543), D_{t}$ is a dummy variable taking the value 1 if $t<0$ and zero otherwise, and $\delta_{t}$ is a dummy variable taking the value 1 at $t$ and zero otherwise. A nonsignificant $\beta_{t}$ for all $t<0$ means that before the call auction the information content of prices remains constant and equal to $\alpha$, the return ratio 30 minutes before the switch. Similarly, a non-significant $\beta_{t}$ for all $t>0$ means that after the call auction the information content of prices remains constant and equal to $\omega$, the return ratio arising from the call auction. To determine whether prices at time $t$ differed from the true value of the stock, the hypotheses tested were

$$
\mathrm{H}_{0}: \alpha+\beta_{t}=1(t<0) \text { and } \mathrm{H}_{0}: \omega+\beta_{t}=1(t>0)
$$

Table 4, Column 3 shows that $\mathrm{H}_{0}$ was rejected before the call but not after the resumption of continuous trading. The results of an analogous analysis of the reference data are likewise consistent with the results shown in Table 3 and commented on above.

\section{[INSERT TABLE 4 HERE]}

The above results show rapid price adjustment and subsequent stability in the 30 minutes following the resolution of call auctions. This finding contrasts with the evidence of erratic prices following trading halts in markets such as Nasdaq (Christie, Corwin, and Harris 2002).

To check on the scope of the above results, their validity was investigated for subsamples representing various different conditions of liquidity, market volatility and time of day, and for the subsamples composed of auctions triggered by static and dynamic price collars (see Tables 2-4).

Although the returns on IBEX-35 shares differed significantly from the close-to-close returns at all times except immediately before and immediately after the auction, they rose during the preauction period and throughout the post-auction period remained stable at about $15 \%$ below the closeto-close returns (Table 2, Column 3). The regression results show convergence to the close-to-close 
return to have already occurred, to within statistical significance, prior to the auction, and to have been maintained thereafter, although the means of the $y_{i, t}$ were slightly depressed by the auction and did not regain values close to unity until 10 minutes later.

In September and October 2001 the market was especially volatile. However, comparison of Columns 2 and 4 of Tables 2 and 4, shows that this general volatility hardly influenced the behaviour of the return ratios of auctioned shares in the half-hours preceding and following volatility auctions.

Comparison of Columns 5, 6 and 7 of Table 2 shows that the return ratios of shares involved in pre-midday volatility auctions were considerably more depressed, prior to the auction, than those auctioned later in the day, and were more benefited by the auction. Returns following pre-midday auctions were stable, but median values remained $10-15 \%$ below the close-to-close return. The returns of shares involved in auctions between midday and mid-afternoon were much better predictors of close-to-close return: the median return ratios rose from 0.68 to 0.84 before the auction, and after it remained within $5 \%$ of unity (within $2 \%$, once the first 10 minutes had elapsed). The statistical behaviour of the returns of shares involved in auctions later than mid-afternoon was very similar to that of the full sample (Column 2). These trends are echoed by the regression results (Table 4, Columns 8-13): of all the subsets of the full sample considered in Table 4, the pre-midday auctions are the only ones for which some of the post-auction $\beta_{\mathrm{t}}$ differ significantly from zero.

The main return ratio trends commented on above (a rise before auctions and as the result of the auction, followed by the maintenance of values near unity over the next half hour) were also independent of whether it was the static or dynamic collar of the share that was responsible for the auction being triggered (see the final columns of Tables 2 and 4). However, when the auction was triggered by the dynamic collar, post-auction return ratios were considerably smaller than when it was triggered by the static collar, around 0.86 as against 0.96 . 


\subsection{Price Volatility}

In this subsection I analyse the impact of the call auction on volatility. Economides (1995) and Schwartz (2001) argue that concentrating liquidity at a single point in time reduces volatility because order arrival time does not affect prices. SSE call auctions, which are triggered during continuous trading as a result of large price changes, provide an opportunity to test this conclusion.

I measure price volatility in the half-hours preceding and following the switch in terms of a) the absolute percentage change between the first and last trading prices, and b) the standard deviation of trading prices. First, for both the auction sample and the reference sample, I compare pre- and post-event price volatility by applying the signed rank test to the after/before ratio; I then evaluate the statistical significance of differences between the two samples by applying the same test to the ratio of ratios.

According to both measures of price volatility, volatility was significantly less in the halfhour following volatility auctions than in the half-hour preceding them (Table 5, Column 2). Median post-event volatility was also less than pre-event volatility in the reference sample, but in this case the difference was not statistically significant. Furthermore, in keeping with the above results on price discovery, the proportional decrease in volatility following auctions was significantly greater than the proportional decrease following reference events (third lines of Panels A and B of Table 5). This behaviour contrasts with reports that volatility rises to anomalously high and persistent levels following trading halts on the NYSE (Lee, Ready, and Seguin 1994; Fong 1996; Corwin and Lipson 2000), intraday trading halts on Nasdaq (Christie, Corwin, and Harris 2002), and the execution of price limits on the Tokyo exchange (Kim and Rhee 1997).

Similar behaviour was shown by the various subsamples considered. In particular, although for IBEX-35 stocks the before-after difference for reference events was statistically significant (this difference from the full sample probably being attributable to the greater liquidity of the market 
index stocks), the reduction in liquidity for these stocks was, as in the full sample, significantly greater following auctions than following reference events.

\section{[INSERT TABLE 5 HERE]}

\subsection{Bid-ask Spread}

The effect of volatility auctions on bid-ask spread was investigated by examining the normalised bid-ask spread in successive 5-minute intervals in the half-hours preceding and following the auction. Normalized bid-ask spread was defined as $\left(P_{\text {ask }}-P_{\text {bid }}\right) / 0.5\left(P_{\text {ask }}+P_{\text {bid }}\right)$, where $P_{\text {ask }}$ and $P_{\text {bid }}$ are the best ask and bid prices on the limit order book at the end of the 5-minute period in question. Figure 3 shows that median normalized 5-minute bid-ask spreads tended to rise in the 10 or 15 minutes preceding a volatility auction and became even higher immediately following the auction. Though they tended to fall thereafter, half-an-hour after the auction they were still considerably higher than half-an-hour before it.

\section{[INSERT FIGURE 3 HERE]}

To evaluate the statistical significance of the above trends, the panel data model

$$
y_{i, t}=\alpha_{i}+\sum_{\substack{t=-5 \\ t \neq 0}}^{6} \beta_{t} d_{t}+\varepsilon_{i, t}
$$

was fitted, where $y_{i, t}$ denotes the spread at time $t$ in switch event $i(i=1, \ldots, 543 ; t$ as in Fig. 3$), d_{t}$ is a dummy variable taking the value 1 at $t$ and zero otherwise, $\beta_{t}$ is the slope coefficient at $t, \alpha_{i}$ is the fixed effect parameter, and $\varepsilon_{i, t}$ is the error term. Significant values of the $\beta_{t}$ indicate significant changes in bid-ask spread. Column 2 of Table 6 shows that, by this criterion, bid-ask spread was significantly larger than pre-event values in the 10 minutes preceding and the 5 minutes following volatility auctions, but did not differ significantly from pre-event values at earlier or later times. 
Fig. 3 shows that bid-ask spreads were relatively stable before reference events and slightly higher immediately following them. To compare this behaviour with that seen around volatility auctions, a paired-sample signed rank test was performed for each 5-minute interval. The results (values in parentheses in Panel B of Table 7) show that, compared with reference values, spreads were significantly larger immediately before auctions and throughout the following half hour. In fact, spreads narrowed more slowly after auctions than after reference events, as is shown by the median excess values

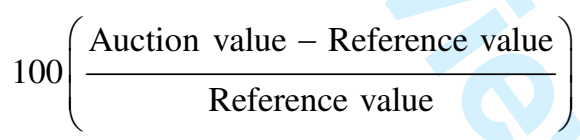

(the values not shown in parentheses in Panel B), spreads narrowed more slowly after auctions than after reference events.

In general, the behaviour described above was also exhibited by the various subsamples that were considered: in almost all cases, bid-ask spread was wider in the 5 or 10 minutes prior to the auction than at earlier times, and remained wide or even increased during at least the first 5 minutes following the auction, after which it narrowed (Tables 6 and 7). In the "normal" reference sample, 
the bid-ask spread remained throughout close to the value shown by the auction sample half-an-hour before the auction (results available on request).

The pre-auction rise in bid-ask spread suggests the effect of an information shock, and means that the volatility auctions considered here, which were triggered by attempted excursion of trading prices outside their constraining collars, would also have been activated by triggers defined in terms of the bid-ask spread exceeding a threshold based on trading volume and the bid-ask spread history of the stock, as proposed by Madhavan (1992).

\subsection{Trading Volume and Intensity}

The abnormally high trading volumes observed in the 30 minutes following trading halts on Nasdaq and the NYSE (Lee et al. 1994; Corwin and Lipson 2000; and Christie et al. 2002) suggest that medium-run trading vigour is unaffected by the halt mechanism regardless of market structure. In this subsection I employ the same tests as in the analysis of bid-ask spread to study whether trading vigour, as reflected by the total volume of shares traded and the number of transactions (both expressed as a percentage of the totals for the day), is affected by volatility auctions on the SSE.

Share trading volume tended to increase rapidly in the 15-20 minutes prior to volatility auctions, especially in the immediately preceding 5 minutes, but within half-an-hour returned to levels similar to those observed half-an-hour before the auction (Fig. 4). This rise and fall in trading volume around the switch is corroborated by the pairwise comparisons of volume listed in Table 8 (Column 2, Panel A) and by the regression test results (Table 9, Column 2), although the increase in volume was only statistically significant during the auction and in the preceding 5 minutes. Much the same trends were observed in the various subsamples considered, except that the peak in trading volume was comparatively flat and broad for IBEX-35 stocks (Column 3) and, to a lesser extent, in 
auctions triggered by the static price collar (Column 8); while, on the contrary, the peak was confined to the auction itself in auctions triggered by the dynamic collar (Column 9), and to the 5 minutes preceding the auction in late afternoon events (Column 7), although trading volume in the latter was in fact quite irregular throughout the hour surrounding the auction.

[INSERT FIGURE 4 HERE]

\section{[INSERT TABLES 8 AND 9 HERE]}

Median reference values fluctuated widely on a 10-20-minute time scale both before and after the reference event (Fig.4). The nearly auction-triggering price jump constituting the event was associated with a particularly high median trading volume peak, but this peak did not stand out much from the general large variability, which contrasted both with the smooth rise and fall of median trading volume that was seen around auctions, and with the behaviour of the "normal" reference sample, in which median trading volume remained throughout close to the values shown by the auction sample half-an-hour before and after the auction (results available on request). Except at the re-opening of continuous trading, paired-sample signed rank tests showed either no significant difference between the auction sample and the volatile reference sample, or that auction sample volumes were significantly lower than reference volumes (Table 8, Panel B); in particular auction sample volumes were significantly lower than reference volumes throughout the 20 minutes before the auction.

When trading activity is measured in terms of the number of trades, the same patterns are observed as when the measure is trading volume (see Fig. 5 and Tables 10 and 11).

In keeping with the results on price discovery and volatility, these results suggest that the assimilation of new information via auctions results in smoother trading behaviour than its assimilation in the absence of an auction.

[INSERT FIGURE 5 HERE] 


\section{[INSERT TABLES 10 AND 11 HERE]}

\section{Conclusions}

The above analysis of data for 543 five-minute, price-triggered switches from continuous to call auction trading on the SSE shows that these events are preceded by an abnormal widening of bid-ask spread. In general, they would therefore have been equally triggered by this parameter, which was the switch-activating trigger originally proposed by Madhavan.

When the day's closing price is used as a proxy for equilibrium price, comparison of price discovery data around volatility auctions with those for reference events (in which auctions were almost but not quite triggered) suggests that auctions are triggered when a rush to capitalize on new information makes its assimilation into prices especially rapid, and that the chief effect of auctions is to dampen subsequent nervousness. In keeping with this interpretation, the proportional decrease in volatility following volatility auctions is significantly greater than following reference events, and the evolution of trading volume and the number of transactions is smoother around auctions than around reference events.

The above trends contrast with those observed in connection with trading halts on the NYSE and Nasdaq (Lee, Ready, and Seguin 1994; Corwin and Lipson 2000; Christie, Corwin, and Harris 2002), where price volatility, bid-ask spread and trading volume all tend to remain high following trading halts. However, these differences in behaviour are difficult to interpret because the structural and operational differences between these exchanges and the SSE are numerous. During volatility auctions trade continues, whereas trade ceases altogether for a more or less lengthy period during trading halts; price and order feedback are unavailable during volatility auctions, whereas they are available during the auctions that terminate NYSE trading halts; the volatility responsible for most SSE volatility auctions appears to arise from uncertainty following news concerning the affected firm or the market in general, whereas most NYSE trading halts are imposed to deal with uncertainty 
before firm-specific announcements; finally, even in normal circumstances, most SSE stocks are considerably less liquid than most NYSE stocks.

It is unfortunate that for this study it was not possible to obtain data on trading behaviour during volatility auctions themselves. Information on order flow and liquidity during the auctions would afford greater insight into traders' behaviour and the learning process, and would provide clues as to the optimal duration of volatility auctions. 


\section{References}

Amihud, Y., Mendelson, H.. (1987) Trading mechanisms and stock returns: An empirical investigation, Journal of Finance 42, 533-553.

Amihud, Y., Mendelson, H.. (1991) Volatility, efficiency and trading: Evidence from the Japanese stock market, Journal of Finance 46, 1765-1790.

Amihud, Y., Mendelson, H., Murgia, M.. (1990) Stock market microstructure and return volatility: Evidence from Italy, Journal of Banking and Finance 14, 423-440.

Biais, B., Hillion, P., Spatt, C. (1999) Price discovery and learning during the preopening period in the Paris Bourse, Journal of Political Economy 107, 1218-1248.

Brown, D.P., Jennings, R.H.. (1989) On technical analysis, Review of Financial Studies 2, 527-552.

Christie, W.G., Corwin, S.A. Harris, J.H. (2002) Nasdaq trading halts: The impact of market mechanisms on prices, trading activity, and execution cost, Journal of Finance 57, 1443-1478.

Corwin, S.A., Lipson, M.L. (2000) Order flow and liquidity around NYSE trading halts, Journal of Finance 55, 1771-1801.

Economides, N. (1995) How to enhance market liquidity. In: R. Schwartz, ed., Global Equities Markets (Irwin Professional, New York).

Economides, N., Schwartz, R.A. (1995) Electronic call market trading, Journal of Portfolio Management 21, $10-18$.

Edelen, R., Gervais, S. (2003) The role of trading halts in monitoring a specialist market, Review of Financial Studies 16, 263-300.

Fong, W.M. (1996) New York Exchange trading halts and volatility, International Review of Economics and Finance 5, 243-257.

Foster, M., George, T. (1996) Pricing effects and the NYSE open and close: Evidence from internationally cross-listed stocks, Journal of Financial Intermediation 5, 95-126.

France, V., Kodres, L., Moser, J. (1994) A review of regulatory mechanisms to control the volatility of prices. Federal Reserve Bank of Chicago, Economic Perspectives 18, 15-28. 
Galper, J. (1999) Management of market volatility: A report to the FIBV working committee for the focus group study, International Federation of Stock Exchanges.

Gerety, M.S., Mulherin, J.H. (1994) Price formation on stock exchanges: The evolution of trading within the day, Review of Financial Studies 7, 609-629.

Greenwald, B.C., Stein, J.C. (1988) The task force report: The reasoning behind the recommendations, Journal of Economic Perspectives 2, 3-23.

Greenwald, B.C., Stein, J.C. (1991) Transactional risk, market crashes, and the role of circuit breakers, Journal of Business 64, 443-462.

Grundy, B.D., McNichols, M. (1989) Trade and revelation of information through prices and direct disclosure, Review of Financial Studies 2, 485-526.

Handa, P., Schwartz, R.A. (1996) How best to supply liquidity to a securities market, Journal of Portfolio Management, Winter, 44-51.

Harris, L. (1998) Circuit breakers and program trading limits: What we have learned? In: Litian, R., Santomero, A. Eds., Brooking-Wharton Papers on Financial Services. Brookings Institutions Press, Washington, 17-63.

Kodres, L.E., O'Brien, D.P. (1994) The existence of Pareto superior price limits, American Economic Review 84, 919-932.

Kim, K.A., Rhee, S.G. (1997) Price limit performance: Evidence from the Tokyo Stock Exchange, Journal of Finance 52, 885-901.

Kim, Y.H., Yang, J.J. (2004) What makes circuit breakers attractive to financial markets? A survey, Financial Markets, Institutions and Instruments 13, 109-146.

Kyle, A.S. (1985) Continuous auctions and insider trading, Econometrica 53, 1315-1335.

Kyle, A.S. (1988) Trading halts and price limits, Review of Futures Markets 7, 426-434.

Lee, C.M.C., Ready, M.J., Seguin, P.J. (1994) Volume, volatility, and New York Stock Exchange trading halts, Journal of Finance 49, 183-214.

Madhavan, A. (1992) Trading mechanisms in securities markets, Journal of Finance 47, 607-641.

Madhavan, A., Panchapagesan, V. (2000) Price discovery in auction markets: A look inside the black box, Review of Financial Studies 13, 627-658. 
Pagano, M., Röell, A. (1996) Transparency and liquidity: A comparison of auction and dealer markets with informed trading, Journal of Finance 51, 579-611.

Pagano, M.S., Schwartz, R.A. (2003) A closing call's impact on market quality at Euronext Paris, Journal of Financial Economics 68, 439-484.

Schnitzlein, C.R. (1996) Call and continuous trading mechanisms under asymmetric information: An experimental investigation, Journal of Finance 51, 613-636.

Schwartz, R.A. (2001) The call auction alternative. In: R.A. Schwartz, ed., The Electronic Call Auction: Market Mechanism and Trading.(Kluwer Academic Publishers, Boston).

Subrahmanyam, A. (1994) Circuit breakers and market volatility: A theoretical perspective, Journal of Finance 49, 237-254

Stoll, H., Whaley, R.E. (1990) Stock market structure and volatility, Review of Financial Studies 3, 37-71.

Theissen, E. (2000) Market structure, information efficiency and liquidity: An experimental comparison of auction and dealer markets, Journal of Financial Markets 3, 333-363. 
Figure 1: Temporal Distribution of Volatility Auctions.

Distribution of 543 volatility auctions that occurred on the SSE between May 2001 and January 2002, by month (A), day of the week (B) and time of day (C).

Panel A: Distribution of volatility auctions by month

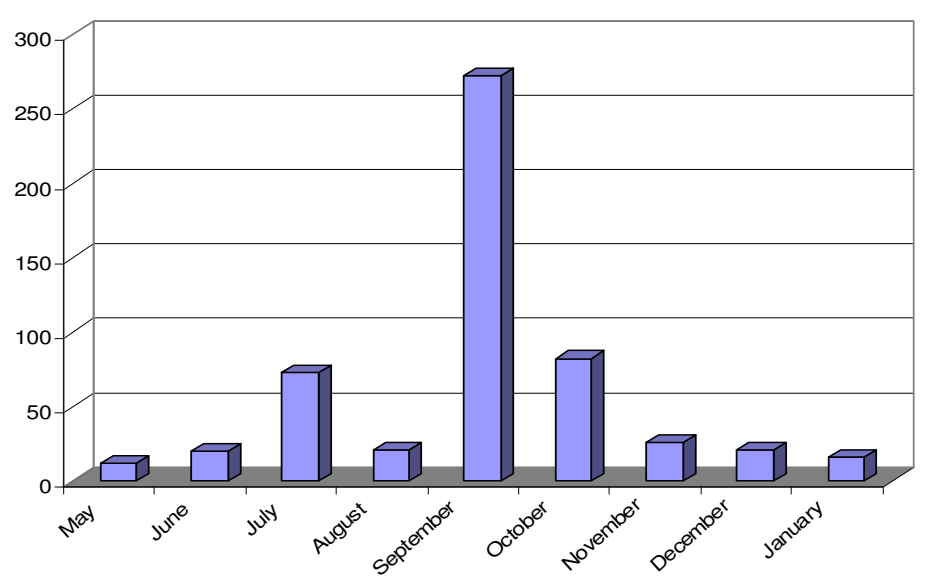

Panel B: Distribution of volatility auctions by day of the week

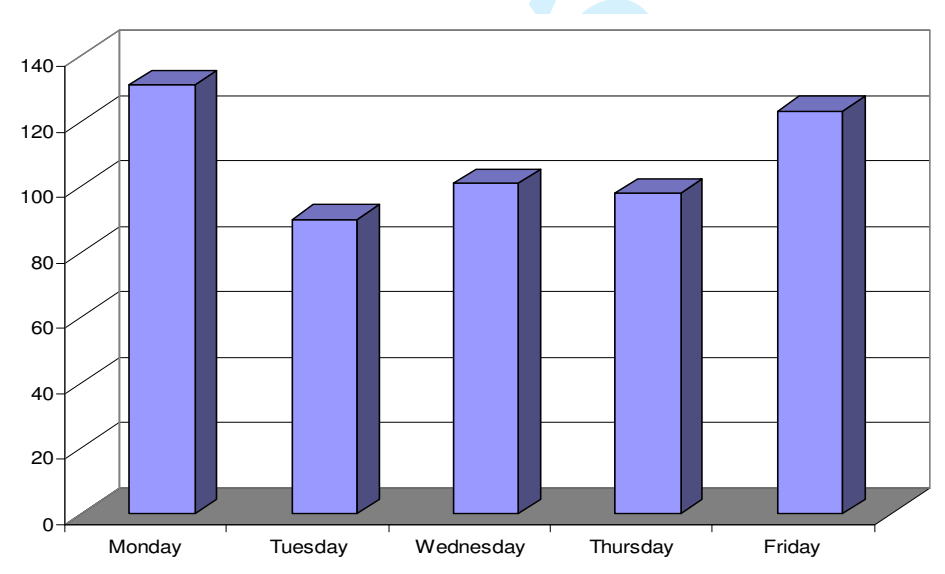


Panel C: Distribution of volatility auctions by time of day.

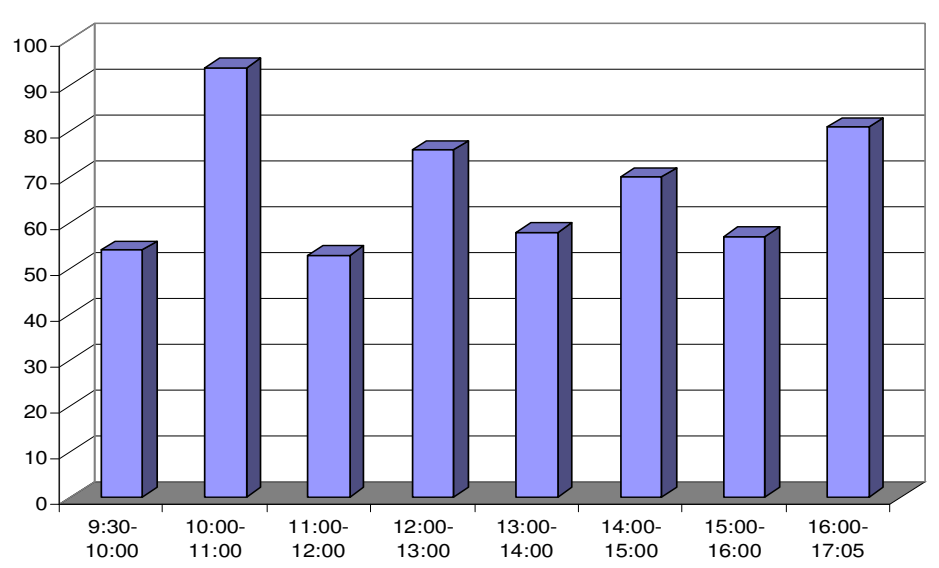


Figure 2: Price Discovery.

Median values of the ratio $\ln \left(P_{t} / P_{T-1}\right) / \ln \left(P_{T} / P_{T-1}\right)$, where $P_{T}$ is closing price, $P_{T-1}$ the previous closing price, and $P_{t}$ the last trading price in successive 5-minute intervals in the half-hours preceding and following the auction, measured backwards from the time of the switch and forward from the resumption of continuous trading. The sample comprised 543 switch events that occurred on the SSE between May 2001 and January 2002.

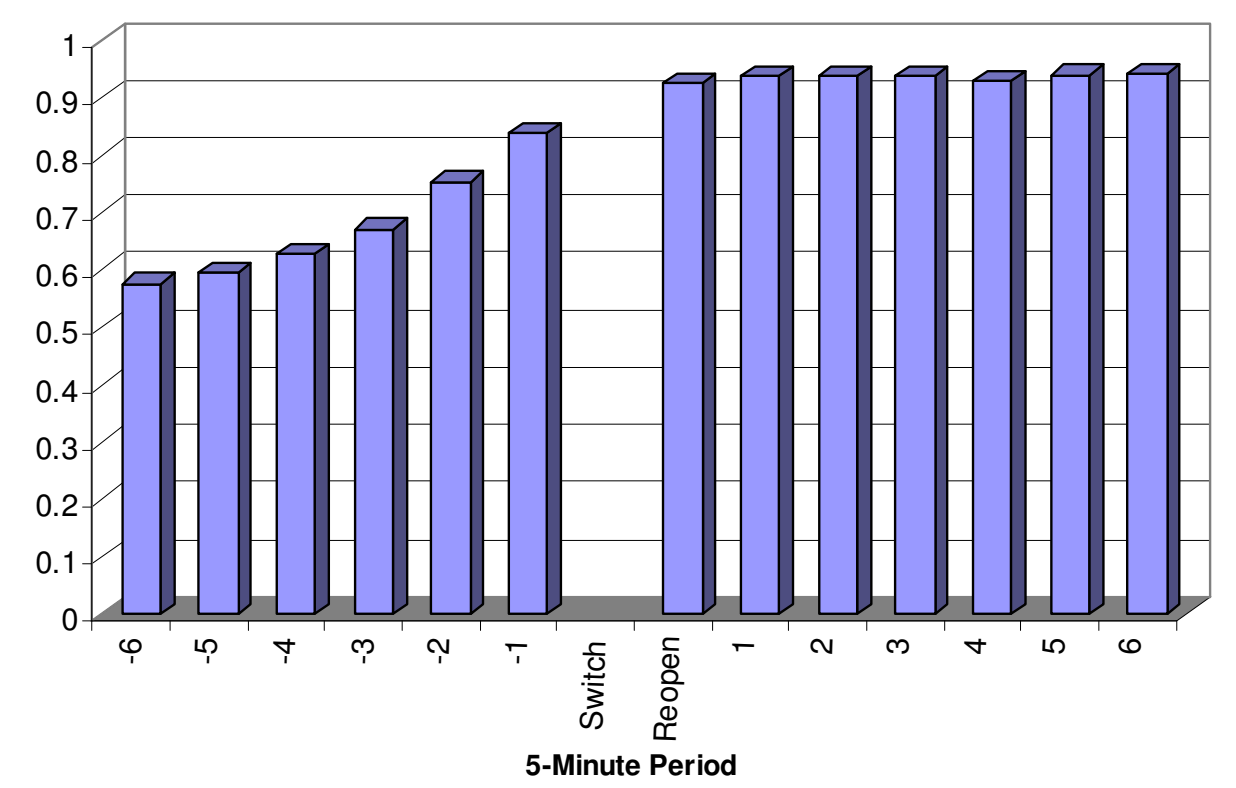


Figure 3: Bid-Ask Spread Around Volatility Auctions and Reference Events.

Median normalized bid-ask spreads, $\left(P_{\text {asked }}-P_{\text {bid }}\right) / 0.5\left(P_{\text {asked }}+P_{\text {bid }}\right)$, in successive 5 -minute intervals in the half-hours preceding and following the auction, measured backwards from its start and forward from the resumption of continuous trading. The sample comprised 543 switch events that occurred on the SSE between May 2001 and January 2002. Analogous data for the reference sample are also shown.

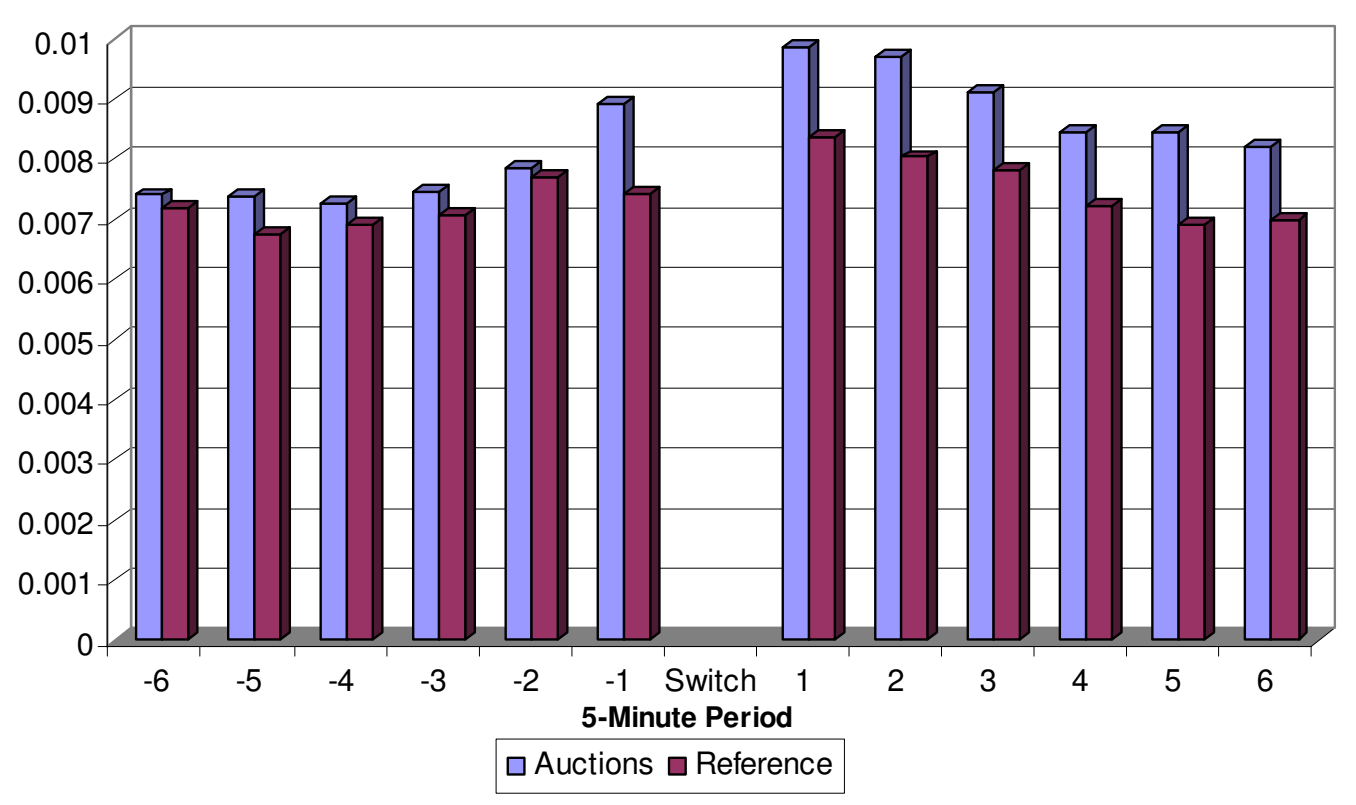


Figure 4: Share Trading Volume Around Volatility Auctions and Reference Events.

Median traded share volume (\% of day's total) in successive 5-minute intervals in the half-hours preceding and following volatility auctions and reference events, measured backwards from the start of the auction or reference event and forward from the resumption of continuous trading.

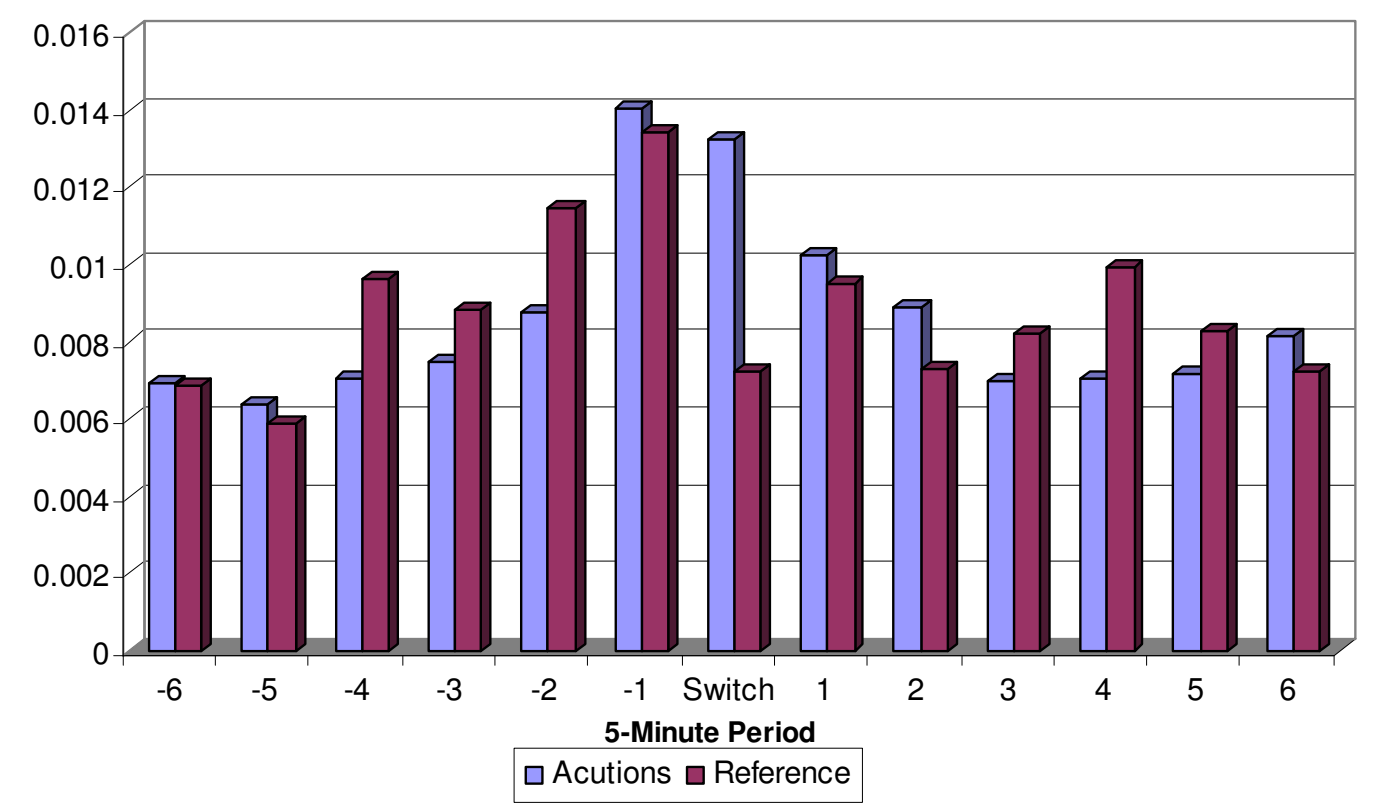


Figure 5: Number of Trades Around Volatility Auctions and Reference Events.

Median number of transactions (\% of day's total) in successive 5-minute intervals in the half-hours preceding and following volatility auctions and reference events, measured backwards from the start of the auction or event and forward from the resumption of continuous trading.

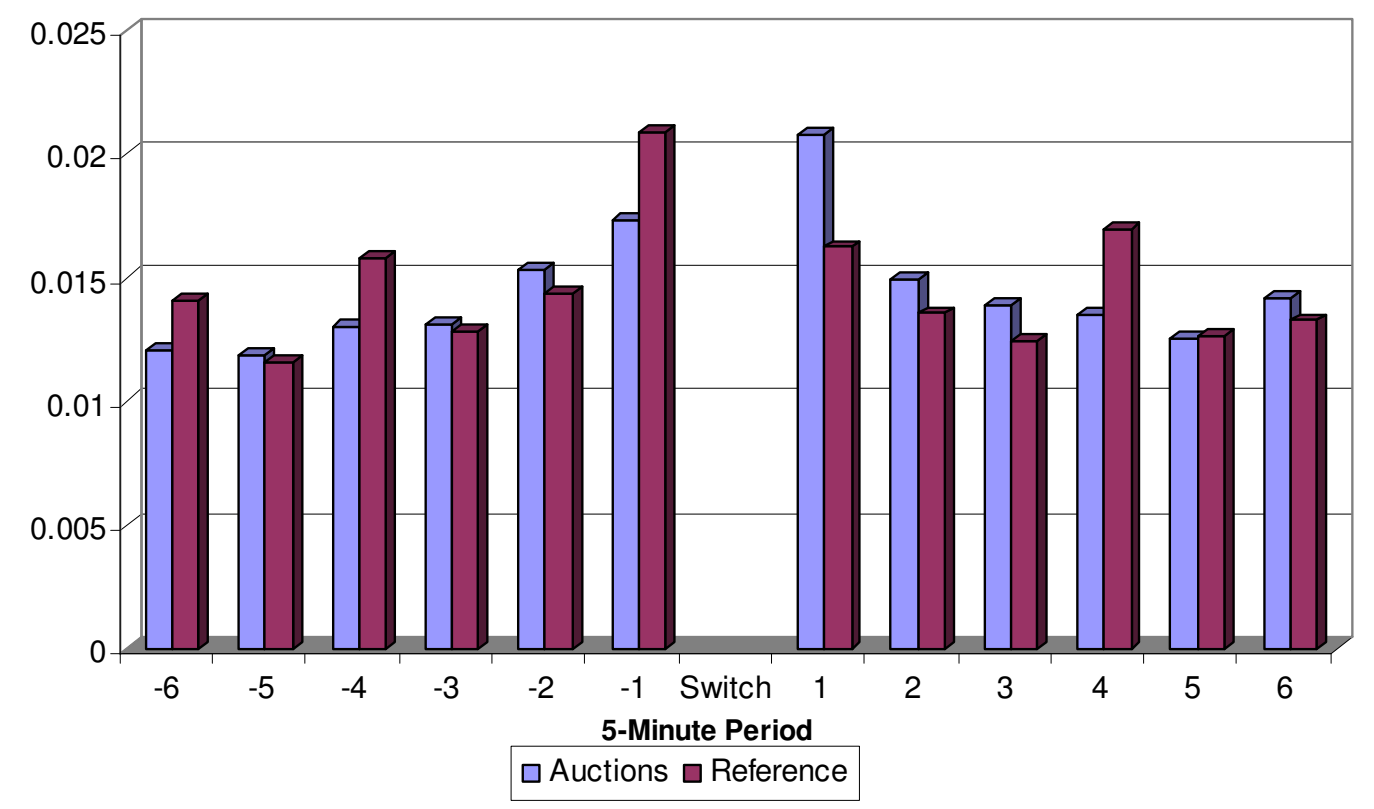


Table 1: Summary Statistics for Stocks involved in Volatility Auctions

Distribution quantiles of volatility auctions on the SSE (May 2001-January 2002) with regard to four characteristics of the stocks involved: closing price on the day of the switch $(€)$, immediately pre-switch inside bid-ask spread (normalized by division by the midpoint of the spread), shares traded on the day (thousands), and transactions on the day.

\begin{tabular}{lccrr}
\hline & Price $(€)$ & Bid-Ask Spread & Share Volume & Trades per Day \\
\hline Full Sample $(n=543)$ & & & & \\
$10^{\text {th }}$ Percentile & 1.32 & 0.0022 & 22 & 24 \\
$25^{\text {th }}$ Percentile & 2.77 & 0.0028 & 63 & 51 \\
Median & 7.75 & 0.0089 & 278 & 155 \\
$75^{\text {th }}$ Percentile & 13.65 & 0.0219 & 1,138 & 603 \\
$90^{\text {th }}$ Percentile & 20.02 & 0.0329 & 3,861 & 1,977 \\
& & & & \\
Market Index Stocks $(n=203)$ & & & & 358 \\
$10^{\text {th }}$ Percentile & 4.65 & 0.0008 & 278 & 455 \\
$25^{\text {th }}$ Percentile & 6.42 & 0.0011 & 406 & 710 \\
Median & 11.36 & 0.0038 & 1,238 & 1,954 \\
$75^{\text {th }}$ Percentile & 17.15 & 0.0101 & 3,861 & 4,466 \\
$90^{\text {th }}$ Percentile & 22.25 & 0.0175 & 26,716 & \\
\hline
\end{tabular}


Table 2: Results of Statistical Tests of Price Discovery Around Volatility Auctions.

Panel A lists median values of the ratio $\ln \left(P_{t} / P_{T-1}\right) / \ln \left(P_{T} / P_{T_{-1}}\right)$, where $P_{T}$ is closing price, $P_{T_{-1}}$ the previous closing price and $P_{t}$ the last trading price in successive 5-minute intervals in the half-hours preceding and following the auction, measured backwards from the time of its start and forward from the resumption of continuous trading; together with signed rank $z$ values (asterisks indicate values that are significantly different from unity at the 5\% level). Panel B lists signed rank $z$ values for comparisons of the ratio $\ln \left(P_{t} / P_{T-1}\right) / \ln \left(P_{T} / P_{T-1}\right)$ at the pairs of times indicated in Column 1 . Panel C lists median values of the mean $\ln \left(P_{t} / P_{T-1}\right) / \ln \left(P_{T} / P_{T-1}\right)$ ratio in the half hours preceding and following the auction, together with signed rank $z$ values (asterisks indicate that post-auction values are significantly greater than pre-auction values at the $5 \%$ level). The sample consisted of 543 volatility auctions on the SSE between May 2001 and January 2002.

\begin{tabular}{|c|c|c|c|c|c|c|c|c|}
\hline Period & $\begin{array}{l}\text { Full Sample } \\
\qquad(n=543)\end{array}$ & $\begin{array}{l}\text { Market Index Stocks } \\
\qquad(n=203)\end{array}$ & $\begin{array}{c}\text { September and } \\
\text { October } \\
(n=354)\end{array}$ & $\begin{array}{c}\text { Time of day: } \\
9: 30-12: 00 \\
(n=201)\end{array}$ & $\begin{array}{l}\text { Time of day: } \\
\text { 12:00-15:00 } \\
(n=204)\end{array}$ & $\begin{array}{l}\text { Time of day: } \\
\text { 15:00-17:00 } \\
(n=138)\end{array}$ & $\begin{array}{l}\text { Triggered by } \\
\text { Static Collar } \\
\quad(n=315)\end{array}$ & $\begin{array}{c}\text { Triggered by } \\
\text { Dynamic Collar } \\
(n=228)\end{array}$ \\
\hline \multicolumn{9}{|l|}{ Panel A } \\
\hline-6 & $0.58(-10.32)^{*}$ & $0.59(-6.10)^{*}$ & $0.57(-7.50)^{*}$ & $0.42(-6.54)^{*}$ & $0.68(-5.16)^{*}$ & $0.57(-6.22)^{*}$ & $0.60(-10.37)^{*}$ & $0.56(-4.04)^{*}$ \\
\hline-5 & $0.59(-10.10)^{*}$ & $0.62(-5.30)^{*}$ & $0.59(-7.32)^{*}$ & $0.45(-6.75)^{*}$ & $0.67(-5.16)^{*}$ & $0.63(-5.47)^{*}$ & $0.62(-9.58)^{*}$ & $0.56(-4.27)^{*}$ \\
\hline-4 & $0.63(-9.65)^{*}$ & $0.69(-4.60)^{*}$ & $0.63(-7.07) *$ & $0.50(-6.51)^{*}$ & $0.70(-4.96) *$ & $0.68(-5.04)^{*}$ & $0.64(-9.65)^{*}$ & $0.63(-3.91)^{*}$ \\
\hline-3 & $0.67(-8.38)^{*}$ & $0.69(-4.52)^{*}$ & $0.68(-5.74) *$ & $0.55(-5.44)^{*}$ & $0.76(-4.29) *$ & $0.73(-4.72)^{*}$ & $0.69(-8.43)^{*}$ & $0.63(-3.27)^{*}$ \\
\hline-2 & $0.75(-7.06)^{*}$ & $0.78(-3.39)^{*}$ & $0.75(-4.71)^{*}$ & $0.60(-4.25)^{*}$ & $0.80(-3.86)^{*}$ & $0.79(-3.94)^{*}$ & $0.75(-7.49)^{*}$ & $0.78(-2.40)^{*}$ \\
\hline-1 & $0.84(-4.24)^{*}$ & $0.87(-1.58)$ & $0.82(-3.05)^{*}$ & $0.70(-2.94)^{*}$ & $0.84(-2.14)^{*}$ & $0.90(-1.97)^{*}$ & $0.84(-4.31)^{*}$ & $0.80(-1.54)$ \\
\hline \multicolumn{9}{|l|}{ Switch } \\
\hline Reopening & $0.93(-1.88)$ & $0.86(-1.70)$ & $0.90(-1.20)$ & $0.87(-2.04)^{*}$ & $0.95(-0.19)$ & $0.93(-0.95)$ & $0.96(-0.80)$ & $0.85(-1.77)$ \\
\hline 1 & $0.94(-1.49)$ & $0.82(-2.45)^{*}$ & $0.94(-0.76)$ & $0.87(-1.31)$ & $0.97(-0.27)$ & $0.95(-0.98)$ & $0.97(-0.43)$ & $0.86(-1.54)$ \\
\hline 2 & $0.94(-1.90)$ & $0.84(-2.17)^{*}$ & $0.94(-1.09)$ & $0.89(-1.92)$ & $0.99(-0.46)$ & $0.94(-0.77)$ & $0.99(-0.88)$ & $0.85(-1.65)$ \\
\hline 3 & $0.94(-1.77)$ & $0.84(-2.28)^{*}$ & $0.94(-0.90)$ & $0.84(-2.07)^{*}$ & $0.99(-0.21)$ & $0.97(-0.58)$ & $0.96(-0.94)$ & $0.84(-1.43)$ \\
\hline 4 & $0.93(-2.37)^{*}$ & $0.83(-2.40)^{*}$ & $0.88(-2.12)^{*}$ & $0.85(-2.26)^{*}$ & $0.98(-0.70)$ & $0.92(-0.98)$ & $0.95(-1.62)$ & $0.86(-1.71)$ \\
\hline 5 & $0.94(-2.35)^{*}$ & $0.86(-2.40)^{*}$ & $0.90(-1.78)$ & $0.86(-2.36)^{*}$ & $0.99(-0.54)$ & $0.95(-1.04)$ & $0.96(-1.84)$ & $0.88(-1.42)$ \\
\hline 6 & $0.94(-2.01)^{*}$ & $0.84(-2.79)^{*}$ & $0.88(-1.45)$ & $0.85(-2.15)^{*}$ & $1.00(-0.46)$ & $0.94(-0.61)$ & $0.96(-1.35)$ & $0.88(-1.43)$ \\
\hline \multicolumn{9}{|l|}{ Panel B } \\
\hline$-1,-3$ & $(8.52)^{*}$ & $(6.29)^{*}$ & $(7.85)^{*}$ & $(5.03)^{*}$ & $(6.31)^{*}$ & $(6.11)^{*}$ & $(10.15)^{*}$ & $(2.59)^{*}$ \\
\hline$-1,-6$ & $(10.77)^{*}$ & $(7.63)^{*}$ & $(8.63)^{*}$ & $(5.26)^{*}$ & $(6.96)^{*}$ & $(6.65)^{*}$ & $(10.99)^{*}$ & $(3.91)^{*}$ \\
\hline 1,3 & $(0.21)$ & $(-0.13)$ & $(0.07)$ & $(0.26)$ & $(0.54)$ & $(-0.44)$ & $(1.20)$ & $(-0.96)$ \\
\hline 1,6 & $(0.98)$ & $(1.03)$ & (1.08) & $(1.11)$ & $(0.36)$ & $(0.11)$ & $(1.22)$ & $(-0.78)$ \\
\hline $1,-1$ & $(3.77)^{*}$ & $(0.38)$ & $(3.46)^{*}$ & $(1.17)$ & $(3.52)^{*}$ & $(2.05)^{*}$ & $(2.91)^{*}$ & $(0.27)$ \\
\hline $3,-3$ & $(9.49)^{*}$ & $(5.29)^{*}$ & $(7.43)^{*}$ & $(4.16)^{*}$ & $(6.92)^{*}$ & $(5.63)^{*}$ & $(7.93)^{*}$ & $(2.84)^{*}$ \\
\hline $6,-6$ & $(10.17)^{*}$ & $(6.39)^{*}$ & $(7.54)^{*}$ & $(4.91)^{*}$ & $(6.55)^{*}$ & $(6.50)^{*}$ & $(8.98)^{*}$ & $(3.80)^{*}$ \\
\hline \multicolumn{9}{|l|}{ Panel C } \\
\hline $\begin{array}{c}\text { Mean test } \\
\text { (after-before) }\end{array}$ & $0.92-0.67(9.47)^{*}$ & $0.85-0.71(5.13)^{*}$ & $0.92-0.68(7.20)^{*}$ & $0.84-0.56(3.96)^{*}$ & $0.95-0.71(6.84)^{*}$ & $0.94-0.71(6.03)^{*}$ & $0.95-0.67(10.78)^{*}$ & $0.84-0.69(2.47)^{*}$ \\
\hline Obs. & 7059 & 2639 & 4602 & 2613 & 2652 & 1794 & 4095 & 2964 \\
\hline
\end{tabular}

Editorial Office, Dept of Economics, Wârwick University, Coventry CV4 7AL, UK 
Table 3: Results of Statistical Tests of Price Discovery for the Reference Sample.

Analyses analogous to those of Panel A of Table 2.

\begin{tabular}{|c|c|c|c|c|c|c|c|c|}
\hline Period & $\begin{array}{l}\text { Full Sample } \\
\quad(n=543)\end{array}$ & $\begin{array}{l}\text { Market Index Stocks } \\
\qquad(n=203)\end{array}$ & $\begin{array}{c}\text { September and } \\
\text { October } \\
(n=354)\end{array}$ & $\begin{array}{l}\text { Time of day: } \\
\text { 9:30-12:00 } \\
(n=201)\end{array}$ & $\begin{array}{c}\text { Time of day: } \\
\text { 12:00-15:00 } \\
(n=204)\end{array}$ & $\begin{array}{l}\text { Time of day: } \\
\text { 15:00-17:00 } \\
(n=138)\end{array}$ & $\begin{array}{l}\text { Triggered by } \\
\text { Static Collar } \\
\quad(n=315)\end{array}$ & $\begin{array}{l}\text { Triggered by } \\
\text { Dynamic Collar } \\
\quad(n=228)\end{array}$ \\
\hline-6 & $0.81(-6.49)^{*}$ & $0.77(-3.85)^{*}$ & $0.80(-4.31)^{*}$ & $0.81(-4.67)^{*}$ & $0.68(-3.66)^{*}$ & $0.83(-2.58)^{*}$ & $0.80(-4.38)^{*}$ & $0.83(-4.93)^{*}$ \\
\hline-5 & $0.82(-6.27)^{*}$ & $0.75(-3.18)^{*}$ & $0.80(-4.21)^{*}$ & $0.79(-4.58)^{*}$ & $0.68(-3.70) *$ & $0.83(-2.26)^{*}$ & $0.84(-4.05)^{*}$ & $0.81(-4.91)^{*}$ \\
\hline-4 & $0.85(-4.57)^{*}$ & $0.72(-2.01)^{*}$ & $0.76(-3.51)^{*}$ & $0.77(-3.93)^{*}$ & $0.70(-2.11)^{*}$ & $0.84(-1.72)$ & $0.90(-2.76)^{*}$ & $0.82(-3.82)^{*}$ \\
\hline-3 & $0.89(-3.25)^{*}$ & $0.83(-0.90)$ & $0.88(-1.57)$ & $0.88(-3.01)^{*}$ & $0.78(-1.67)$ & $0.93(-0.79)$ & $0.95(-1.88)$ & $0.90(-2.90)^{*}$ \\
\hline-2 & $0.93(-1.20)$ & $0.81(0.73)$ & $0.86(-0.44)$ & $0.88(-1.41)$ & $0.81(-0.68)$ & $0.96(0.29)$ & $1.01(-0.29)$ & $0.91(-1.65)$ \\
\hline-1 & $0.99(1.21)$ & $0.92(-3.04)^{*}$ & $0.95(1.42)$ & $0.96(0.17)$ & $0.90(0.92)$ & $1.05(3.12)^{*}$ & $1.12(2.07)^{*}$ & $0.98(0.83)$ \\
\hline 1 & $1.10(2.92)^{*}$ & $0.92(-3.75)^{*}$ & $0.98(1.37)$ & $1.13(2.36)^{*}$ & $1.05(2.25)^{*}$ & $1.07(5.16)^{*}$ & $1.09(3.04)^{*}$ & $1.07(2.47)^{*}$ \\
\hline 2 & $0.96(-2.08)^{*}$ & $1.05(-3.40)^{*}$ & $1.09(4.32)^{*}$ & $0.93(-1.98)^{*}$ & $0.95(-2.26)^{*}$ & $1.20(3.34)^{*}$ & $1.04(3.38)^{*}$ & $0.96(1.89)$ \\
\hline 3 & $0.95(-2.07)^{*}$ & $0.91(-2.51)^{*}$ & $0.95(-2.63)^{*}$ & $0.93(1.94)$ & $0.95(-1.62)$ & $1.02(2.58)^{*}$ & $1.01(2.55)^{*}$ & $0.94(1.18)$ \\
\hline 4 & $0.97(1.71)$ & $0.92(-2.84)^{*}$ & $0.95(-2.13)^{*}$ & $0.98(0.30)$ & $0.99(1.95)$ & $1.03(2.45)^{*}$ & $1.02(1.86)$ & $0.96(0.78)$ \\
\hline 5 & $0.94(-2.69)^{*}$ & $0.95(1.16)^{*}$ & $1.01(3.96)^{*}$ & $0.94(-2.02)^{*}$ & $0.95(-2.28)^{*}$ & $1.06(2.75)^{*}$ & $1.05(2.55)^{*}$ & $0.94(0.91)$ \\
\hline 6 & $1.00(1.01)$ & $0.90(-2.35)^{*}$ & $0.95(-2.20)^{*}$ & $1.01(0.48)$ & $1.01(2.02)^{*}$ & $1.02(2.25)^{*}$ & $1.03(2.26)^{*}$ & $0.99(-0.36)$ \\
\hline
\end{tabular}

Editorial Office, Dept of Economics, Wärwick University, Coventry CV4 7AL, UK 
Table 4: Results of the Regression Test of Price Discovery Around Volatility Auctions.

This table summarizes the results of fitting the panel data regression model

$$
y_{i, t}=D_{t}\left(\alpha+\sum_{t=-5}^{-1} \beta_{t} \delta_{t}\right)+\left(1-D_{t}\right)\left(\omega+\sum_{t=1}^{6} \beta_{t} \delta_{t}\right)+\varepsilon_{i, t},
$$

where $i$ indexes the switch event $(i=1, \ldots, 543), t$ denotes successive 5 -minute intervals in the half-hours preceding $(t=-1, \ldots,-6)$ and following the auction $(t=0,1, \ldots, 6$; the auction ends at $t=0), D_{t}$ is a dummy variable taking the value 1 if $t<0$ and zero otherwise, and $\delta_{t}$ is a dummy variable taking the value 1 at $t$ and zero otherwise. The dependent variable is the ratio $\ln \left(P_{t} / P_{T-1}\right) / \ln \left(P_{T} / P_{T-1}\right)$, where $P_{t}$ is the last trading price, $P_{T}$ is the closing price and $P_{T_{-1}}$ is the previous day's closing price. The table reports the estimated coefficients and the results of statistical tests of the null hypothesis that the return ratio $y_{i t}$, equals unity $\left(F\right.$ tests of $\mathrm{H}_{0}: \alpha+\beta_{t}=1$ for $t=-5, \ldots,-1$, and of $\mathrm{H}_{0}: \omega+\beta_{t}=1$ for $t>0 ; t$ tests of $\mathrm{H}_{0}: \alpha=1$ for $\mathrm{t}=-6$ and of $\mathrm{H}_{0}: \omega=1$ for $\mathrm{t}=0$ ). Asterisks indicate rejection of the null hypothesis at the $5 \%$ level using White robust standard errors.

\begin{tabular}{|c|c|c|c|c|c|c|c|c|c|c|c|c|c|c|c|c|}
\hline \multirow{3}{*}{$\begin{array}{c}\text { Period } \\
\alpha\end{array}$} & \multicolumn{2}{|c|}{$\begin{array}{l}\text { Full Sample } \\
\quad(n=543)\end{array}$} & \multicolumn{2}{|c|}{$\begin{array}{l}\text { Market Index Stocks } \\
\qquad(n=203)\end{array}$} & \multicolumn{2}{|c|}{$\begin{array}{l}\text { September and } \\
\text { October } \\
(n=354)\end{array}$} & \multicolumn{2}{|c|}{$\begin{array}{c}\text { Time of the day: } \\
9: 30-12: 00 \\
(n=201)\end{array}$} & \multicolumn{2}{|c|}{$\begin{array}{l}\text { Time of the day: } \\
\text { 12:00-15:00 } \\
(n=204)\end{array}$} & \multicolumn{2}{|c|}{$\begin{array}{c}\text { Time of the day: } \\
\text { 15:00-17:00 } \\
(n=138)\end{array}$} & \multicolumn{2}{|c|}{$\begin{array}{l}\text { Triggered by } \\
\text { Static Collar } \\
\quad(n=315)\end{array}$} & \multicolumn{2}{|c|}{$\begin{array}{l}\text { Triggered by } \\
\text { Dynamic Collar } \\
\quad(n=228)\end{array}$} \\
\hline & \multicolumn{2}{|c|}{$\left(\mathrm{H}_{0}: y_{i, t}=1\right)$} & \multicolumn{2}{|c|}{$\left(\mathrm{H}_{0}: y_{i, t}=1\right)$} & \multicolumn{2}{|c|}{$\left(\mathrm{H}_{0}: y_{i, t}=1\right)$} & \multicolumn{2}{|c|}{$\left(\mathrm{H}_{0}: y_{i, t}=1\right)$} & \multicolumn{2}{|c|}{$\left(\mathrm{H}_{0}: y_{i, t}=1\right)$} & \multicolumn{2}{|c|}{$\left(\mathrm{H}_{0}: y_{i, t}=1\right)$} & \multicolumn{2}{|c|}{$\left(\mathrm{H}_{0}: y_{i, t}=1\right)$} & \multicolumn{2}{|c|}{$\left(\mathrm{H}_{0}: y_{i, t}=1\right)$} \\
\hline & 0.595 & $(-5.75)^{*}$ & 0.649 & $(-2.97)^{*}$ & 0.516 & $(-5.76)^{*}$ & 0.583 & $(-5.27)^{*}$ & 0.759 & $(-3.11)^{*}$ & 0.566 & $(-5.54)^{*}$ & 0.494 & $(-7.89)^{*}$ & 0.708 & $(-3.24)^{*}$ \\
\hline$\beta_{-5}$ & 0.035 & $(24.45)^{*}$ & 0.152 & $(3.95)^{*}$ & 0.021 & $(24.88)^{*}$ & -0.014 & $(33.22)^{*}$ & -0.012 & $(12.10)^{*}$ & 0.022 & $(22.16)^{*}$ & 0.034 & $(51.18)^{*}$ & -0.039 & $(14.17)^{*}$ \\
\hline$\beta_{-4}$ & 0.062 & $(21.11)^{*}$ & 0.157 & $(3.86)^{*}$ & 0.038 & $(23.23)^{*}$ & 0.030 & $(26.69)^{*}$ & -0.021 & $(12.91)^{*}$ & 0.077 & $(16.77)^{*}$ & 0.058 & $(46.72)^{*}$ & -0.002 & $(11.21)^{*}$ \\
\hline$\beta_{-3}$ & 0.094 & $(17.30)^{*}$ & 0.178 & $(3.23)$ & 0.121 & $(15.48)^{*}$ & 0.062 & $(22.55)^{*}$ & -0.006 & $(11.45)^{*}$ & 0.173 & $(8.98)^{*}$ & 0.152 & $(17.30)^{*}$ & 0.054 & $(7.37)^{*}$ \\
\hline$\beta_{-2}$ & 0.204 & $(7.23)^{*}$ & 0.249 & $(0.50)$ & 0.221 & $(8.14)^{*}$ & 0.138 & $(13.84)^{*}$ & 0.085 & $(4.47)^{*}$ & 0.233 & $(5.36)^{*}$ & 0.214 & $(21.67)^{*}$ & 0.142 & $(3.88)^{*}$ \\
\hline$\beta_{-1}$ & 0.269 & $(4.31)^{*}$ & 0.289 & $(0.20)$ & 0.311 & $(3.92)^{*}$ & 0.232 & $(6.09)^{*}$ & 0.138 & (1.97) & 0.335 & $(1.29)$ & 0.293 & $(12.74)^{*}$ & 0.136 & (3.29) \\
\hline \multicolumn{17}{|l|}{ Switch } \\
\hline$\omega$ & 0.954 & $(-0.51)$ & 0.888 & $(-0.77)$ & 0.936 & $(-0.64)$ & 0.922 & $(-1.01)$ & 1.072 & $(0.71)$ & 0.965 & $(-0.40)$ & 1.001 & $(-0.51)$ & 0.855 & $(-1.37)$ \\
\hline$\beta_{1}$ & 0.021 & $(0.06)$ & -0.045 & $(0.73)$ & 0.021 & $(0.16)$ & 0.060 & $(0.70)$ & -0.027 & $(0.58)$ & -0.027 & $(0.70)$ & 0.046 & $(0.33)$ & 0.061 & $(0.72)$ \\
\hline$\beta_{2}$ & 0.010 & $(0.15)$ & 0.119 & $(0.20)$ & -0.001 & $(0.37)$ & -0.035 & (3.37) & -0.019 & $(0.77)$ & -0.019 & $(0.51)$ & -0.022 & $(0.69)$ & 0.099 & $(0.26)$ \\
\hline$\beta_{3}$ & 0.032 & $(0.02)$ & 0.108 & $(0.01)$ & 0.025 & $(0.13)$ & -0.007 & $(1.90)$ & -0.016 & $(0.53)$ & -0.016 & $(0.46)$ & 0.031 & $(0.15)$ & 0.114 & $(0.16)$ \\
\hline$\beta_{4}$ & 0.013 & $(0.12)$ & 0.098 & $(0.04)$ & 0.010 & $(0.26)$ & -0.040 & $(3.86)^{*}$ & -0.021 & $(0.34)$ & -0.021 & $(0.56)$ & -0.052 & $(0.38)$ & 0.076 & $(0.50)$ \\
\hline$\beta_{5}$ & 0.004 & $(0.21)$ & -0.007 & $(0.42)$ & -0.006 & $(0.44)$ & -0.027 & $(3.08)$ & 0.010 & $(0.44)$ & 0.010 & $(0.10)$ & -0.060 & $(0.51)$ & 0.175 & $(0.15)$ \\
\hline$\beta_{6}$ & 0.050 & $(0.02)$ & 0.050 & $(0.11)$ & 0.043 & $(0.32)$ & -0.054 & $(4.84)^{*}$ & -0.004 & $(0.43)$ & -0.004 & $(0.25)$ & 0.002 & $(0.01)$ & 0.165 & (0.10) \\
\hline Obs. & \multicolumn{2}{|r|}{7059} & \multicolumn{2}{|c|}{2639} & \multicolumn{2}{|c|}{4602} & \multicolumn{2}{|c|}{2613} & \multicolumn{2}{|c|}{2652} & \multicolumn{2}{|c|}{1794} & \multicolumn{2}{|c|}{4095} & \multicolumn{2}{|c|}{2964} \\
\hline
\end{tabular}

Editorial Office, Dept of Economics, Wärwick University, Coventry CV4 7AL, UK 
Table 5: Price Volatility Changes Around Volatility Auctions and Reference Events.

The table lists, for both the auction sample and the reference sample, median values of the ratio between post- and pre-event volatility as measured by the absolute percentage first-last price change and price standard deviation; and also, median values of the ratio of the auction and reference sample ratios. Values of $z$ for signed rank comparisons with unity are shown in parentheses (asterisks indicate values that are significant at the 5\% level).

\begin{tabular}{|c|c|c|c|c|c|c|c|c|}
\hline Period $^{\mathrm{a}}$ & $\begin{array}{l}\text { Full Sample } \\
\quad(n=543)\end{array}$ & $\begin{array}{c}\text { Market Index } \\
\text { Stocks } \\
(n=203)\end{array}$ & $\begin{array}{c}\text { September and } \\
\text { October } \\
(n=354)\end{array}$ & $\begin{array}{c}\text { Time of day: } \\
9: 30-12: 00 \\
(n=201)\end{array}$ & $\begin{array}{l}\text { Time of day: } \\
\text { 12:00-15:00 } \\
(n=204)\end{array}$ & $\begin{array}{l}\text { Time of day: } \\
\text { 15:00-17:00 } \\
(n=138)\end{array}$ & $\begin{array}{l}\text { Triggered by } \\
\text { Static Collar } \\
\quad(n=315)\end{array}$ & $\begin{array}{c}\text { Triggered by } \\
\text { Dynamic Collar } \\
\quad(n=228)\end{array}$ \\
\hline \multicolumn{9}{|l|}{ Panel A: Absolute Percentage Price Change } \\
\hline $\mathrm{AE} / \mathrm{BE}$ (auctions) & $0.50(-7.95)^{*}$ & $0.45(-8.13)^{*}$ & $0.50(-7.04)^{*}$ & $0.45(-5.09)^{*}$ & $0.66(-3.80)^{*}$ & $0.50(-4.72)^{*}$ & $0.52(-7.11)^{*}$ & $0.50(-3.96)^{*}$ \\
\hline $\mathrm{AE} / \mathrm{BE} \quad$ (reference sample) & $0.81(-1.27)$ & $0.63(-5.28)^{*}$ & $0.73(-1.28)$ & $0.75(-2.13)^{*}$ & $0.79(1.31)$ & $0.84(-1.83)$ & $0.76(-1.34)$ & $0.79(-0.96)$ \\
\hline$(\mathrm{AE} / \mathrm{BE}$ auctions $) /(\mathrm{AE} / \mathrm{BE}$ reference sample) & $0.74(2.11)^{*}$ & $0.90(2.38)^{*}$ & $0.81(2.33)^{*}$ & $0.76(2.01)^{*}$ & $0.72(-2.22)^{*}$ & $0.77(1.98)^{*}$ & $0.83(-2.68)^{*}$ & $0.80(2.10)^{*}$ \\
\hline \multicolumn{9}{|l|}{ Panel B: Standard Deviation } \\
\hline $\mathrm{AE} / \mathrm{BE}$ (auctions) & $0.72(-3.90)^{*}$ & $0.65(-6.86)^{*}$ & $0.72(-3.79)^{*}$ & $0.66(-2.21)^{*}$ & $0.74(1.85)$ & $0.76(-2.72)^{*}$ & $0.72(-3.86)^{*}$ & $0.71(-1.98)^{*}$ \\
\hline $\mathrm{AE} / \mathrm{BE} \quad$ (reference sample) & $0.85(-0.74)$ & $0.67(-4.61)^{*}$ & $0.74(0.92)$ & $0.76(1.21)$ & $0.86(-0.42)$ & $0.85(-1.78)$ & $0.85(-1.29)$ & $0.87(1.01)$ \\
\hline (AE/BE auctions)/(AE/BE reference sample) & $0.91(-2.02)^{*}$ & $0.96(2.43)^{*}$ & $0.95(-1.89)$ & $0.92(1.43)$ & $0.88(-4.46)^{*}$ & $0.90(1.87)$ & $0.92(-2.02)^{*}$ & $0.92(2.03)^{*}$ \\
\hline
\end{tabular}

${ }^{\mathrm{a}} \mathrm{AE}=$ After Event; BE = Before Event. 
Table 6: Results of Comparisons of Normalized Bid-Ask Spread Around Volatility Auctions and Reference Events.

Panel A lists signed rank $z$ values for comparisons of normalized bid-ask spread in the auction sample at the pairs of times indicated in Column 1. Panel B lists, for successive 5-minute intervals, the median percentage difference in normalized bid-ask spread between the auction and reference samples, together with $z$ values resulting from the corresponding paired-sample signed rank tests. Asterisks indicate statistical significance at the 5\% level.

\begin{tabular}{|c|c|c|c|c|c|c|c|c|}
\hline Period & $\begin{array}{l}\text { Full Sample } \\
\quad(n=543)\end{array}$ & $\begin{array}{l}\text { Market Index Stocks } \\
\qquad(n=203)\end{array}$ & $\begin{array}{c}\text { September and } \\
\text { October } \\
(n=354)\end{array}$ & $\begin{array}{c}\text { Time of day: } \\
9: 30-12: 00 \\
(n=201)\end{array}$ & $\begin{array}{l}\text { Time of day: } \\
\text { 12:00-15:00 } \\
(n=204)\end{array}$ & $\begin{array}{l}\text { Time of day: } \\
\text { 15:00-17:00 } \\
(n=138)\end{array}$ & $\begin{array}{l}\text { Triggered by } \\
\text { Static Collar } \\
\quad(n=315)\end{array}$ & $\begin{array}{l}\text { Triggered by } \\
\text { Dynamic Collar } \\
\quad(n=228)\end{array}$ \\
\hline \multicolumn{9}{|l|}{ Panel A } \\
\hline$-1,-3$ & $(1.56)$ & $(3.54)^{*}$ & (1.17) & $(2.45)^{*}$ & $(3.56)^{*}$ & $(0.80)$ & $(3.08)^{*}$ & $(5.49)^{*}$ \\
\hline$-1,-6$ & $(2.29)^{*}$ & $(3.19)^{*}$ & $(1.97)^{*}$ & $(2.54)^{*}$ & $(2.89)^{*}$ & $(0.93)$ & $(2.29)^{*}$ & $(5.44)^{*}$ \\
\hline 1,3 & $(5.21)^{*}$ & $(2.76)^{*}$ & $(3.82)^{*}$ & $(2.85)^{*}$ & $(2.40)^{*}$ & (1.78) & $(3.18)^{*}$ & $(4.24) *$ \\
\hline 1,6 & $(5.41)^{*}$ & $(4.33)^{*}$ & $(4.05)^{*}$ & $(3.53)^{*}$ & $(2.78)^{*}$ & $(1.91)$ & $(3.48)^{*}$ & $(4.22)^{*}$ \\
\hline $1,-1$ & $(0.05)$ & $(1.38)$ & $(0.21)$ & $(-2.22)^{*}$ & $(-2.22)^{*}$ & $(1.05)$ & $(4.07)^{*}$ & $(-3.61)^{*}$ \\
\hline $3,-3$ & $(0.66)$ & $(1.46)$ & $(0.44)$ & $(-0.40)$ & $(-0.40)$ & $(1.22)$ & $(0.14)$ & $(0.75)$ \\
\hline $6,-6$ & $(0.92)$ & $(1.06)$ & $(-0.54)$ & $(-2.76)^{*}$ & $(-2.76)$ & $(0.81)$ & $(-0.50)$ & $(0.88)$ \\
\hline \multicolumn{9}{|l|}{ Panel B } \\
\hline-6 & $7.45(1.12)$ & $4.96(1.04)$ & $2.55(1.30)$ & $8.04(2.32)^{*}$ & $8.15(-0.63)$ & $7.10(1.05)$ & $0.15(-0.91)$ & $7.07(1.87)$ \\
\hline-5 & $5.65(1.19)$ & $5.65(0.66)$ & $3.99(1.13)$ & $6.60(1.30)$ & $6.61(-0.33)$ & $5.87(0.19)$ & $2.10(-1.20)$ & $5.87(1.06)$ \\
\hline-4 & $7.17(0.61)$ & $6.18(0.22)$ & $6.62(0.73)$ & $9.80(1.45)$ & $8.91(0.21)$ & $7.54(0.20)$ & $3.46(-0.45)$ & $7.06(2.15)^{*}$ \\
\hline-3 & $7.42(0.80)$ & $5.20(0.61)$ & $5.41(0.73)$ & $8.16(1.91)$ & $8.49(1.05)$ & $7.17(0.81)$ & $3.25(0.27)$ & $6.35(1.59)$ \\
\hline-2 & $7.54(2.48)^{*}$ & $7.20(0.64)$ & $7.08(1.28)$ & $8.05(1.97)^{*}$ & $8.52(1.84)$ & $7.42(0.66)$ & $2.07(1.16)$ & $7.51(3.32)^{*}$ \\
\hline-1 & $7.52(2.37)^{*}$ & $8.10(1.66)$ & $7.59(2.01)^{*}$ & $11.15(2.68)^{*}$ & $8.55(1.86)$ & $7.61(0.11)$ & $4.73(4.41)^{*}$ & $7.52(4.18)^{*}$ \\
\hline \multicolumn{9}{|l|}{ Switch } \\
\hline 1 & $7.67(2.90)^{*}$ & $5.91(2.17)^{*}$ & $8.35(2.42)^{*}$ & $11.32(3.04)^{*}$ & $7.86(2.43)^{*}$ & 7.67 (1.63) & $4.29(2.02)^{*}$ & $7.33(6.17)^{*}$ \\
\hline 2 & $11.56(2.98)^{*}$ & $7.98(1.65)$ & $12.09(2.38)^{*}$ & $12.06(2.63)^{*}$ & $10.49(2.67)^{*}$ & $9.16(1.34)$ & $5.01(2.46)^{*}$ & $9.44(5.28)^{*}$ \\
\hline 3 & $10.04(2.18)^{*}$ & $8.01(1.15)$ & $8.39(2.55)^{*}$ & $13.10(10.72)^{*}$ & $11.29(2.45)^{*}$ & $9.95(1.16)$ & $3.62(0.25)$ & $10.28(4.87)^{*}$ \\
\hline 4 & $10.39(2.34)^{*}$ & $8.24(0.41)$ & $9.33(3.08)^{*}$ & $12.30(2.45)^{*}$ & 8.85 (1.56) & $9.41(1.20)$ & $1.93(0.20)$ & $10.57(4.24)^{*}$ \\
\hline 5 & $10.27(2.29)^{*}$ & $7.92(0.47)$ & $9.05(2.51)^{*}$ & $12.51(2.12)^{*}$ & 9.83 (1.59) & $9.38(1.80)$ & $3.17(0.69)$ & $10.27(3.36)^{*}$ \\
\hline 6 & $8.87(2.34)^{*}$ & $7.67(0.69)$ & $6.97(1.82)$ & $9.05(1.53)$ & $10.22(2.43)^{*}$ & $9.24(1.12)$ & $4.36(0.78)$ & $9.05(3.54) *$ \\
\hline
\end{tabular}

Editorial Office, Dept of Economics, wärwick University, Coventry CV4 7AL, UK 
Table 7: Results of the Regression Test of Bid-Ask Spread Around Volatility Auctions.

This table summarizes the results of fitting the panel data regression model

$$
y_{i, t}=\alpha_{i}+\sum_{\substack{t=-5 \\ t \neq 0}}^{6} \beta_{t} d_{t}+\varepsilon_{i, t}
$$

where $y_{i, t}$ denotes the spread recorded in event $i(i=1, \ldots, 543)$ in the $t$-th 5 -minute interval preceding the auction $(t=-1, \ldots,-6)$ or following it $(t=1, \ldots, 6), d_{t}$ is a dummy variable taking the value 1 at $t$ and zero otherwise, and $\varepsilon_{i, t}$ is the error term. The sample comprised 543 volatility auctions on the Spanish Stock Exchange between May 2001 and January 2002. Student's $t$-statistics are shown in parentheses; * denotes statistical significance at the $1 \%$ level.

\begin{tabular}{|c|c|c|c|c|c|c|c|c|}
\hline Period & $\begin{array}{l}\text { Full Sample } \\
\qquad(n=543)\end{array}$ & $\begin{array}{l}\text { Market Index Stocks } \\
\qquad(n=203)\end{array}$ & $\begin{array}{c}\text { September and } \\
\text { October } \\
(n=354)\end{array}$ & $\begin{array}{c}\text { Time of day: } \\
9: 30-12: 00 \\
(n=201)\end{array}$ & $\begin{array}{l}\text { Time of day: } \\
\text { 12:00-15:00 } \\
(n=204)\end{array}$ & $\begin{array}{l}\text { Time of day: } \\
\text { 15:00-17:00 } \\
\quad(n=138)\end{array}$ & $\begin{array}{l}\text { Triggered by } \\
\text { Static Collar } \\
\quad(n=315)\end{array}$ & $\begin{array}{c}\text { Triggered by } \\
\text { Dynamic Collar } \\
(n=228)\end{array}$ \\
\hline$\beta_{-5}$ & $-0.0001(-0.18)$ & $-0.0004(-1.36)$ & $-0.0001(-0.26)$ & $-0.0003(-0.42)$ & $0.0004(0.67)$ & $-0.0002(-0.33)$ & $0.0002(0.49)$ & $-0.0006(-1.03)$ \\
\hline$\beta_{-4}$ & $0.0001(0.02)$ & $-0.0003(-1.09)$ & $-0.0002(-0.05)$ & $-0.0005(-0.70)$ & $0.0007(1.20)$ & $0.0001(0.25)$ & $0.0004(0.81)$ & $-0.0005(-0.83)$ \\
\hline$\beta_{-3}$ & $0.0002(0.70)$ & $-0.0001(-0.36)$ & $0.0001(0.36)$ & $0.0001(0.12)$ & $0.0010(1.73)$ & $-0.0002(-0.34)$ & $0.0002(0.40)$ & $0.0004(0.76)$ \\
\hline$\beta_{-2}$ & $0.0009(2.38)^{*}$ & $0.0003(1.12)$ & $0.0009(1.89)$ & $0.0006(0.84)$ & $0.0019(3.37)^{*}$ & $0.0005(0.71)$ & $0.0007(1.54)$ & $0.0009(1.40)$ \\
\hline$\beta_{-1}$ & $0.0016(3.99)^{*}$ & $0.0018(5.76)^{*}$ & $0.0012(2.48)^{*}$ & $0.0018(2.39)^{*}$ & $0.0012(2.08)^{*}$ & $0.0015(2.15)^{*}$ & $0.0014(2.60)^{*}$ & $0.0040(6.32)^{*}$ \\
\hline \multicolumn{9}{|l|}{ Switch } \\
\hline$\beta_{1}$ & $0.0011(2.77)^{*}$ & $0.0008(2.62)^{*}$ & $0.0009(1.98)^{*}$ & $-0.0003(-0.44)$ & $0.0026(4.41)^{*}$ & $0.0016(2.42)^{*}$ & $0.0013(2.68)^{*}$ & $0.0012(1.99)^{*}$ \\
\hline$\beta_{2}$ & $0.0006(1.57)$ & $0.0004(1.47)$ & $0.0006(1.22)$ & $-0.0004(-0.59)$ & $0.0017(3.01)^{*}$ & $0.0013(1.86)$ & $0.0007(1.52)$ & $0.0007(1.15)$ \\
\hline$\beta_{3}$ & $0.0001(0.40)$ & $-0.0003(-0.10)$ & $0.000(0.10)$ & $-0.0009(-1.28)$ & $0.0012(2.18)^{*}$ & $0.0009(1.39)$ & $0.0006(1.22)$ & $-0.0001(-0.72)$ \\
\hline$\beta_{4}$ & $-0.0002(-0.68)$ & $-0.0002(-0.69)$ & $-0.0003(-0.74)$ & $-0.0018(-2.45)^{*}$ & $0.0010(1.78)$ & $0.0005(0.79)$ & $0.0001(0.36)$ & $-0.0010(-1.60)$ \\
\hline$\beta_{5}$ & $-0.0003(-0.86)$ & $-0.0003(-0.90)$ & $-0.0002(-0.53)$ & $-0.0022(-2.94)^{*}$ & $0.0004(0.81)$ & $0.0015(2.22)^{*}$ & $0.0002(0.50)$ & $-0.0012(-1.89)$ \\
\hline$\beta_{6}$ & $-0.0005(-1.22)$ & $-0.0005(-1.58)$ & $-0.0005(-1.01)$ & $-0.0020(-2.73)^{*}$ & $0.0006(1.11)$ & $0.0004(0.69)$ & $0.0001(-0.16)$ & $-0.0011(-1.81)$ \\
\hline Adj. $\mathrm{R}^{2}$ & 0.68 & 0.38 & 0.65 & 0.69 & 0.66 & 0.66 & 0.72 & 0.62 \\
\hline F-Statistic & 25.94 & 8.03 & 22.20 & 26.16 & 22.86 & 22.64 & 30.33 & 19.65 \\
\hline Obs. & 6516 & 2436 & 4248 & 2412 & 2448 & 1656 & 3780 & 2736 \\
\hline
\end{tabular}

Editorial Office, Dept of Economics, Wẩwick University, Coventry CV4 7AL, UK 
Table 8: Results of Comparisons of Trading Volume Around Volatility Auctions and Reference Events.

Panel A lists signed rank $z$ values for comparisons of trading volume (\% of day's total) at the pairs of times indicated in Column 1. Panel B lists, for successive 5-minute intervals, the median percentage difference in trading volume between the auction and reference samples, together with $z$ values resulting from the corresponding pairedsample signed rank tests. Asterisks indicate statistical significance at the $5 \%$ level.

\begin{tabular}{|c|c|c|c|c|c|c|c|c|}
\hline Period & $\begin{array}{l}\text { Full Sample } \\
\qquad(n=543)\end{array}$ & $\begin{array}{l}\text { Market Index Stocks } \\
\qquad(n=203)\end{array}$ & $\begin{array}{c}\text { September and } \\
\text { October } \\
(n=354)\end{array}$ & $\begin{array}{l}\text { Time of day: } \\
9: 30-12: 00 \\
(n=201)\end{array}$ & $\begin{array}{l}\text { Time of day: } \\
\text { 12:00-15:00 } \\
(n=204)\end{array}$ & $\begin{array}{l}\text { Time of day: } \\
15: 00-17: 00 \\
\quad(n=138)\end{array}$ & $\begin{array}{l}\text { Triggered by } \\
\text { Static Collar } \\
\quad(n=315)\end{array}$ & $\begin{array}{c}\text { Triggered by } \\
\text { Dynamic Collar } \\
(n=228)\end{array}$ \\
\hline \multicolumn{9}{|l|}{ Panel A } \\
\hline$-1,-3$ & $(5.26)^{*}$ & $(3.74)^{*}$ & $(3.87)^{*}$ & $(2.82)^{*}$ & $(3.26)^{*}$ & $(2.88)^{*}$ & $(3.79)^{*}$ & $(3.83)^{*}$ \\
\hline$-1,-6$ & $(4.63)^{*}$ & $(4.52)^{*}$ & $(2.72)^{*}$ & $(2.29)^{*}$ & $(2.83)^{*}$ & $(2.82)^{*}$ & $(4.23)^{*}$ & $(2.11)^{*}$ \\
\hline 1,3 & $(5.16)^{*}$ & $(3.14)^{*}$ & $(3.31)^{*}$ & $(2.40)^{*}$ & $(3.59)^{*}$ & $(3.06)^{*}$ & $(5.14)^{*}$ & $(1.68)$ \\
\hline 1,6 & $(3.71)^{*}$ & $(2.59)^{*}$ & $(1.83)$ & $(2.78)^{*}$ & $(2.07)^{*}$ & $(1.54)$ & $(4.17)^{*}$ & $(0.60)$ \\
\hline $1,-1$ & $(-2.93)^{*}$ & $(-2.60)^{*}$ & $(-2.37)^{*}$ & $(-1.70)$ & $(-2.33)^{*}$ & $(1.10)$ & $(-1.37)$ & $(-3.18)^{*}$ \\
\hline $3,-3$ & $(-0.18)$ & $(-0.39)$ & $(0.78)$ & $(-1.01)$ & $(-0.21)$ & $(0.70)$ & $(0.15)$ & $(-0.46)$ \\
\hline $6,-6$ & $(0.26)$ & $(0.61)$ & $(0.51)$ & $(-1.18)$ & $(-1.23)$ & (1.84) & $(0.83)$ & $(-0.70)$ \\
\hline \multicolumn{9}{|l|}{ Panel B } \\
\hline-6 & $-1.53(-1.82)$ & $-2.88(-1.87)$ & $-11.17(-1.88)$ & $-5.74(-1.43)$ & $-9.79(-1.24)$ & $-2.21(-0.41)$ & $2.01(0.07)$ & $-1.73(-2.76)^{*}$ \\
\hline-5 & $6.33(-0.25)$ & $1.15(0.64)$ & $6.03(-0.56)$ & $6.03(0.22)$ & $-2.08(-1.47)$ & $6.62(0.88)$ & $6.91(0.56)$ & $6.03(-1.08)$ \\
\hline-4 & $-12.01(-1.99)^{*}$ & $-15.80(-2.44)^{*}$ & $-15.71(-2.47)^{*}$ & $-11.96(-1.72)$ & $-13.20(-3.29)^{*}$ & $-12.06(1.94)$ & $5.57(0.50)$ & $-12.74(-3.64)^{*}$ \\
\hline-3 & $-18.87(-2.34)^{*}$ & $-19.46(-1.92)$ & $-16.72(2.42)^{*}$ & $-12.46(-0.51)$ & $-13.41(-2.07)^{*}$ & $-20.16(-1.55)$ & $-10.93(-2.08)^{*}$ & $-26.20(-1.24)$ \\
\hline-2 & $-10.23(-2.74)^{*}$ & $-16.41(-2.71)^{*}$ & $-15.41(-2.36)^{*}$ & $-11.82(-2.41)^{*}$ & $10.55(-2.10)^{*}$ & $-10.43(0.02)$ & $-12.06(-1.30)$ & $-9.07(-2.59)^{*}$ \\
\hline-1 & $-12.90(-3.98)^{*}$ & $-16.50(-4.12)^{*}$ & $-12.55(-4.01)^{*}$ & $-13.59(-3.01)^{*}$ & $-15.56(-2.43)^{*}$ & $-13.19(-1.24)$ & $-9.59(-2.63) *$ & $-13.52(-2.96)^{*}$ \\
\hline \multicolumn{9}{|l|}{ Switch } \\
\hline Reopening & $37.01(2.83)^{*}$ & $12.61(-1.19)$ & $15.39(2.51)^{*}$ & $22.36(0.20)$ & $40.91(2.15)^{*}$ & $36.27(2.60)^{*}$ & $19.07(3.13)^{*}$ & $43.27(2.01)$ \\
\hline 1 & $-43.78(-7.80)^{*}$ & $-46.16(-7.61)^{*}$ & $-42.12(-8.75)^{*}$ & $-45.02(-3.67) *$ & $-42.57(-4.95)^{*}$ & $-43.05(-4.93)^{*}$ & $-35.01(-7.64)^{*}$ & $-43.98(-3.11)^{*}$ \\
\hline 2 & $2.57(1.12)$ & $2.81(1.02)$ & $1.97(1.08)$ & $-9.91(-1.38)$ & $-9.78(0.13)$ & $3.05(3.16)^{*}$ & $12.04(3.06)^{*}$ & $-2.09(-2.01)^{*}$ \\
\hline 3 & $-14.89(-1.39)$ & $-2.92(-0.09)$ & $-8.72(-1.54)$ & $-12.41(-0.83)$ & $-20.11(-3.21)^{*}$ & $-12.44(1.72)$ & $14.51(1.11)$ & $-16.89(-3.44)^{*}$ \\
\hline 4 & $-10.05(-3.64) *$ & $-10.70(-1.87)$ & $-21.45(-3.85)^{*}$ & $-14.46(-2.86)^{*}$ & $-29.03(-3.64)^{*}$ & $-12.98(0.82)$ & $0.33(-1.01)$ & $-22.90(-4.15)^{*}$ \\
\hline 5 & $-10.27(-1.56)$ & $-8.54(-1.67)$ & $-14.48(-1.78)$ & $-15.68(-1.89)$ & $-9.95(-2.72)^{*}$ & $-9.81(1.02)$ & $5.98(0.60)$ & $-10.95(-3.09)^{*}$ \\
\hline 6 & $3.96(0.40)$ & $-4.24(-0.06)$ & $-4.24(0.38)$ & $-13.45(-1.29)$ & $-10.29(-0.40)$ & $3.96(1.80)$ & 9.15 (1.77) & $3.71(-1.69)$ \\
\hline
\end{tabular}

Editorial Office, Dept of Economics, Warrwick University, Coventry CV4 7AL, UK 
Table 9: Results of the Regression Test of Trading Volume around Volatility Auctions.

This table summarizes the results of fitting the panel data regression model

$$
y_{i, t}=\alpha_{i}+\sum_{t=-5}^{6} \beta_{t} d_{t}+\varepsilon_{i, t}
$$

where $y_{i, t}$ denotes trading volume (\% of daily trading volume) in the $t$-th 5 -minute interval preceding $(t=-1, \ldots,-6)$ or following $(t=0,1, \ldots, 6)$ the $i$-th auction $(i=1, \ldots, 543) ; d_{t}$ is a dummy variable taking the value 1 at $t$ and zero otherwise; and $\varepsilon_{i, t}$ is the error term. The sample comprised 543 volatility auctions on the Spanish Stock Exchange between May 2001 and January 2002. Values of $t$-statistics are given in parentheses; * denotes statistical significance at the $1 \%$ level.

\begin{tabular}{|c|c|c|c|c|c|c|c|c|}
\hline Period & $\begin{array}{l}\text { Full Sample } \\
\qquad(n=543)\end{array}$ & $\begin{array}{l}\text { Market Index Stocks } \\
\qquad(n=203)\end{array}$ & $\begin{array}{c}\text { September and } \\
\text { October } \\
(n=354)\end{array}$ & $\begin{array}{c}\text { Time of day: } \\
9: 30-12: 00 \\
(n=201)\end{array}$ & $\begin{array}{l}\text { Time of day: } \\
12: 00-15: 00 \\
(n=204)\end{array}$ & $\begin{array}{c}\text { Time of day: } \\
15: 00-17: 00 \\
(n=138)\end{array}$ & $\begin{array}{l}\text { Triggered by } \\
\text { Static Collar } \\
(n=315)\end{array}$ & $\begin{array}{c}\text { Triggered by } \\
\text { Dynamic Collar } \\
(n=228)\end{array}$ \\
\hline$\beta_{-5}$ & $-0.0042(-2.55)^{*}$ & $-0.0001(-0.15)$ & $-0.0040(-2.46)^{*}$ & $-0.0068(-2.30)^{*}$ & $-0.0049(-1.60)$ & $-0.0036(-1.24)$ & $-0.0047(-2.14)^{*}$ & $-0.0047(-1.71)$ \\
\hline$\beta_{-4}$ & $-0.0015(-0.93)$ & $0.0010(1.10)$ & $-0.0038(-2.32)^{*}$ & $-0.0050(-1.69)$ & $-0.0016(-0.53)$ & $-0.0001(-0.01)$ & $-0.0007(-0.32)$ & $-0.0044(-1.57)$ \\
\hline$\beta_{-3}$ & $0.0003(0.23)$ & $0.0012(1.30)$ & $-0.0022(-1.36)$ & $0.0017(0.58)$ & $-0.0033(-1.07)$ & $0.0068(2.31)^{*}$ & $0.0029(1.34)$ & $-0.0022(-0.79)$ \\
\hline$\beta_{-2}$ & $0.0008(0.52)$ & $0.0037(3.94)^{*}$ & $0.0012(0.74)$ & $-0.0019(0.66)$ & $0.0014(0.47)$ & $0.0048(1.67)$ & $0.0019(0.90)$ & $-0.0003(-0.11)$ \\
\hline$\beta_{-1}$ & $0.0086(5.22)^{*}$ & $0.0051(5.28)^{*}$ & $0.0045(2.76)^{*}$ & $0.0077(2.65)^{*}$ & $0.0087(2.83)^{*}$ & $0.0106(3.67)^{*}$ & $0.0113(5.28)^{*}$ & $0.0043(1.52)$ \\
\hline \multicolumn{9}{|l|}{ Switch } \\
\hline$\beta_{0}$ (Reopening) & $0.0110(7.03)^{*}$ & $0.0046(4.90)^{*}$ & $0.0047(3.08)^{*}$ & $0.0108(3.99)^{*}$ & $0.0163(5.71)^{*}$ & $0.0031(1.12)$ & $0.0046(2.26)^{*}$ & $0.0210(8.11)^{*}$ \\
\hline$\beta_{1}$ & $0.0024(1.47)$ & $0.0032(3.33)^{*}$ & $-0.0001(-0.06)$ & $-0.0010(-0.36)$ & $0.0033(1.08)$ & $0.0046(1.58)$ & $0.0045(2.09)^{*}$ & $-0.0014(-0.52)$ \\
\hline$\beta_{2}$ & $0.0005(0.34)$ & $0.0022(2.32)^{*}$ & $-0.0002(-0.13)$ & $-0.0032(-1.09)$ & $-0.0024(-0.80)$ & $0.0057(1.98)^{*}$ & $0.0031(1.44)$ & $-0.0041(-1.47)$ \\
\hline$\beta_{3}$ & $-0.0042(-2.56)^{*}$ & $0.0008(0.85)$ & $-0.0037(-2.27)^{*}$ & $-0.0047(-1.64)$ & $-0.0078(-2.50)^{*}$ & $-0.0020(-0.70)$ & $-0.0035(-1.62)$ & $-0.0051(-1.83)$ \\
\hline$\beta_{4}$ & $-0.0036(-2.16)^{*}$ & $0.0002(0.24)$ & $-0.0047(-2.47)^{*}$ & $-0.0055(-1.91)$ & $-0.0048(-1.57)$ & $0.0007(0.26)$ & $-0.0020(-0.93)$ & $-0.0066(-2.38) *$ \\
\hline$\beta_{5}$ & $-0.0037(-2.18)^{*}$ & $0.0006(0.64)$ & $-0.0032(-1.98)^{*}$ & $-0.0063(-2.15)^{*}$ & $-0.0044(-1.41)$ & $-0.0008(-0.28)$ & $-0.0026(-1.22)$ & $-0.0054(-1.90)$ \\
\hline$\beta_{6}$ & $-0.0021(-1.31)$ & $0.0010(1.13)$ & $-0.0027(-1.66)$ & $-0.0063(-2.17)^{*}$ & $-0.0039(-1.25)$ & $0.0025(0.88)$ & $-0.0021(-0.96)$ & $-0.0041(-1.45)$ \\
\hline Adj. $\mathrm{R}^{2}$ & 0.26 & 0.16 & 0.26 & 0.26 & 0.24 & 0.27 & 0.25 & 0.30 \\
\hline F-Statistic & 4.26 & 4.35 & 4.36 & 3.98 & 3.86 & 4.50 & 4.06 & 4.63 \\
\hline Obs. & 7059 & 2639 & 4602 & 2613 & 2652 & 1794 & 4095 & 2964 \\
\hline
\end{tabular}

Editorial Office, Dept of Economics, Warwick University, Coventry CV4 7AL, UK 
Table 10: Results of Comparisons of Numbers of Transactions Around Volatility Auctions and Reference Events.

Panel A lists signed rank $z$ values for comparisons of numbers of transactions (\% of daily total) at the pairs of times indicated in Column 1 . Panel B lists, for successive 5-minute intervals, the median percentage difference in numbers of transactions between the auction and reference samples, together with $z$ values resulting from the corresponding paired-sample signed rank tests. Asterisks indicate statistical significance at the 5\% level.

\begin{tabular}{|c|c|c|c|c|c|c|c|c|}
\hline Period & $\begin{array}{l}\text { Full Sample } \\
\quad(n=543)\end{array}$ & $\begin{array}{l}\text { Market Index Stocks } \\
\qquad(n=203)\end{array}$ & $\begin{array}{c}\text { September and } \\
\text { October } \\
(n=354)\end{array}$ & $\begin{array}{c}\text { Time of day: } \\
\text { 9:30-12:00 } \\
(n=201)\end{array}$ & $\begin{array}{c}\text { Time of day: } \\
\text { 12:00-15:00 } \\
(n=204)\end{array}$ & $\begin{array}{c}\text { Time of day: } \\
15: 00-17: 00 \\
(n=138)\end{array}$ & $\begin{array}{l}\text { Triggered by } \\
\text { Static Collar } \\
\quad(n=315)\end{array}$ & $\begin{array}{c}\text { Triggered by } \\
\text { Dynamic Collar } \\
\quad(n=228)\end{array}$ \\
\hline \multicolumn{9}{|l|}{ Panel A } \\
\hline$-1,-3$ & $(4.34)^{*}$ & $(3.47)^{*}$ & $(2.75)^{*}$ & $(2.81)^{*}$ & $(2.49)^{*}$ & $(2.21)^{*}$ & $(2.85)^{*}$ & $(2.03)^{*}$ \\
\hline$-1,-6$ & $(5.20)^{*}$ & $(4.48)^{*}$ & $(3.58)^{*}$ & (1.91) & $(4.22)^{*}$ & $(2.97)^{*}$ & $(4.35)^{*}$ & $(3.15)^{*}$ \\
\hline 1,3 & $(7.28)^{*}$ & $(5.57)^{*}$ & $(5.45)^{*}$ & $(4.33)^{*}$ & $(3.88)^{*}$ & $(4.51)^{*}$ & $(6.89)^{*}$ & $(5.35)^{*}$ \\
\hline 1,6 & $(6.25)^{*}$ & $(3.84)^{*}$ & $(3.71)^{*}$ & $(4.66)^{*}$ & $(4.24)^{*}$ & (1.69) & $(5.32)^{*}$ & $(3.91)^{*}$ \\
\hline $1,-1$ & $(1.12)$ & $(0.03)$ & $(0.22)$ & $(0.70)$ & $(0.55)$ & $(0.72)$ & $(2.33)^{*}$ & $(2.57)^{*}$ \\
\hline $3,-3$ & $(1.78)$ & $(-0.08)$ & $(0.43)$ & $(0.48)$ & $(1.55)$ & $(1.91)$ & $(1.53)$ & $(1.23)$ \\
\hline $6,-6$ & (1.09) & $(1.30)$ & $(1.21)$ & $(1.73)$ & $(0.17)$ & $(3.20) *$ & $(1.99) *$ & $(1.59)$ \\
\hline \multicolumn{9}{|l|}{ Panel B } \\
\hline-6 & $-5.34(-0.97)$ & $-5.41(-0.90)$ & $-4.76(-0.62)$ & $-2.57(0.78)$ & $-5.38(-3.07)^{*}$ & $-4.55(0.49)$ & $-4.34(-0.59)$ & $-4.69(-0.78)$ \\
\hline-5 & $-9.52(-1.90)$ & $-10.86(-0.76)$ & $-5.60(-1.37)$ & $-2.30(0.51)$ & $-10.86(-3.44)^{*}$ & $-8.88(-0.77)$ & $-8.33(-1.46)$ & $-9.62(-1.25)$ \\
\hline-4 & $-13.90(-3.27)^{*}$ & $-13.93(-3.20)^{*}$ & $-12.69(-3.19) *$ & $-12.56(-1.07)$ & $-19.56(-4.01)^{*}$ & $-15.32(-0.42)$ & $-15.82(-1.51)$ & $-14.75(-3.28)^{*}$ \\
\hline-3 & $-3.03(-0.75)$ & $-3.93(0.18)$ & $-1.91(-0.30)$ & $-1.04(0.92)$ & $-3.48(-2.42)^{*}$ & $-3.93(-0.06)$ & $-9.28(-0.93)$ & $-3.04(-0.21)$ \\
\hline-2 & $-3.12(-1.41)$ & $1.09(-0.25)$ & $4.69(-1.04)$ & $4.38(-0.22)$ & $-3.89(-2.32)^{*}$ & $3.20(0.08)$ & $-1.76(-0.55)$ & $-2.53(-1.36)$ \\
\hline-1 & $-16.07(-3.26)^{*}$ & $-12.58(-3.72)^{*}$ & $-14.10(-3.19)^{*}$ & $-16.36(-2.43) *$ & $-18.58(-2.41)^{*}$ & $-12.95(-0.80)$ & $-15.38(-2.51)^{*}$ & $-16.09(-1.99) *$ \\
\hline \multicolumn{9}{|l|}{ Switch } \\
\hline 1 & $16.11(2.87)^{*}$ & $16.81(1.41)$ & $12.63(1.45)$ & $12.82(2.36)$ & $8.67(-0.43)$ & $17.01(2.80)^{*}$ & $18.55(3.62)^{*}$ & $16.06(0.14)$ \\
\hline 2 & $7.66(1.21)$ & $7.49(1.74)$ & $7.27(0.29)$ & $7.84(0.82)$ & $7.38(-1.20)$ & $7.84(2.26)^{*}$ & $11.04(2.22)^{*}$ & $7.24(-0.70)$ \\
\hline 3 & $6.63(1.02)$ & $4.38(1.18)$ & $6.21(0.98)$ & $5.06(0.61)$ & $3.73(-1.79)$ & $5.80(2.97)^{*}$ & $11.85(1.34)$ & $6.21(0.01)$ \\
\hline 4 & $-9.64(-3.34)^{*}$ & $-8.75(-1.67)$ & $-12.32(-3.42)^{*}$ & $-11.38(-3.17)^{*}$ & $-10.38(-4.16)^{*}$ & $-12.64(1.74)$ & $-1.62(-1.05)$ & $-13.25(-3.79)^{*}$ \\
\hline 5 & $-8.12(-1.92)$ & $-5.56(-1.44)$ & $-7.35(-2.55)^{*}$ & $-10.35(-2.02)^{*}$ & $-10.81(-3.24)^{*}$ & $-8.85(1.91)$ & $-0.22(0.56)$ & $-10.35(-3.56)^{*}$ \\
\hline 6 & $-4.61(-0.77)$ & $-5.07(-0.81)$ & $-6.59(-1.56)$ & $-6.40(-1.55)$ & $-8.95(-1.84)$ & $-4.20(1.94)$ & $2.22(1.26)$ & $4.89(-2.71)^{*}$ \\
\hline
\end{tabular}

Editorial Office, Dept of Economics, Warwick University, Coventry CV4 7AL, UK 


\section{Page 43 of 44}

\section{Submitted Manuscript}

Editorial Office, Dept of Economics, Warwick University, Coventry CV4 7AL, UK 
Table 11: Results of the Regression Test of the Number of Transactions Around Volatility Auctions.

This table summarizes the results of fitting the panel data regression mode

$$
y_{i, t}=\alpha_{i}+\sum_{\substack{t=-5 \\ t \neq 0}}^{6} \beta_{t} d_{t}+\varepsilon_{i, t}
$$

where $y_{i, t}$ denotes number of transactions (\% of the daily total) in the $t$-th 5 -minute interval preceding $(t=-1, \ldots,-6)$ or following $(t=1, \ldots, 6)$ the $i$-th auction $(i=1, \ldots, 543) ; d_{t}$ is a dummy variable taking the value 1 at $t$ and zero otherwise; and $\varepsilon_{i, t}$ is the error term. The sample comprised 543 volatility auctions on the Spanish Stock Exchange between May 2001 and January 2002. Values of $t$-statistics are given in parentheses; * denotes statistical significance at the $1 \%$ level.

\begin{tabular}{|c|c|c|c|c|c|c|c|c|}
\hline Period & $\begin{array}{l}\text { Full Sample } \\
\qquad(n=543)\end{array}$ & $\begin{array}{l}\text { Market Index Stocks } \\
\qquad(n=203)\end{array}$ & $\begin{array}{c}\text { September and } \\
\text { October } \\
(n=354)\end{array}$ & $\begin{array}{c}\text { Time of day: } \\
\text { 9:30-12:00 } \\
(n=201)\end{array}$ & $\begin{array}{c}\text { Time of day: } \\
\text { 12:00-15:00 } \\
(n=204)\end{array}$ & $\begin{array}{l}\text { Time of day: } \\
15: 00-17: 00 \\
(n=138)\end{array}$ & $\begin{array}{l}\text { Triggered by } \\
\text { Static Collar } \\
\quad(n=315)\end{array}$ & $\begin{array}{c}\text { Triggered by } \\
\text { Dynamic Collar } \\
(n=228)\end{array}$ \\
\hline$\beta_{-5}$ & $-0.0013(-0.94)$ & $-0.0003(-0.44)$ & $-0.0016(-1.01)$ & $-0.0022(-1.05)$ & $-0.0007(-0.35)$ & $-0.0003(-0.13)$ & $-0.0010(-0.62)$ & $-0.0016(-0.74)$ \\
\hline$\beta_{-4}$ & $-0.0001(-0.21)$ & $0.0002(0.58)$ & $-0.0004(-0.46)$ & $-0.0005(-0.47)$ & $0.0008(0.72)$ & $0.0001(0.09)$ & $-0.0001(-0.18)$ & $-0.0005(-0.34)$ \\
\hline$\beta_{-3}$ & $-0.0008(-0.65)$ & $0.0001(0.21)$ & $-0.0009(-0.72)$ & $-0.0014(-0.76)$ & $-0.0001(-0.10)$ & $0.0002(0.12)$ & $-0.0004(-0.27)$ & $-0.0015(-0.76)$ \\
\hline$\beta_{-2}$ & $0.0013(0.92)$ & $0.0019(2.20)^{*}$ & $0.0004(0.27)$ & $0.0011(0.51)$ & $0.0023(1.13)$ & $0.0014(0.49)$ & $0.0014(0.74)$ & $0.0010(0.42)$ \\
\hline$\beta_{-1}$ & $0.0049(4.20)^{*}$ & $0.0033(4.41)^{*}$ & $0.0036(2.89)^{*}$ & $0.0056(3.07)^{*}$ & $0.0055(3.17)^{*}$ & $0.0060(3.02)^{*}$ & $0.0063(4.22)^{*}$ & $0.0051(2.82)^{*}$ \\
\hline \multicolumn{9}{|l|}{ Switch } \\
\hline$\beta_{1}$ & $0.0070(7.10)^{*}$ & $0.0032(4.51)^{*}$ & $0.0052(4.51)^{*}$ & $0.0058(3.61)^{*}$ & $0.0087(5.45)^{*}$ & $0.0077(3.96)^{*}$ & $0.0080(5.84)^{*}$ & $0.0053(3.16)^{*}$ \\
\hline$\beta_{2}$ & $0.0013(1.13)$ & $0.0017(2.33)^{*}$ & $-0.0003(-0.23)$ & $0.0005(0.29)$ & $0.0019(1.05)$ & $0.0031(1.53)$ & $0.0022(1.57)$ & $0.0004(0.23)$ \\
\hline$\beta_{3}$ & $0.0002(0.13)$ & $0.0001(0.40)$ & $-0.0004(-0.54)$ & $-0.0007(-0.63)$ & $0.0021(1.80)$ & $0.0010(0.71)$ & $0.0001(0.09)$ & $-0.0003(-0.22)$ \\
\hline$\beta_{4}$ & $0.0001(0.04)$ & $0.0004(0.54)$ & $-0.0006(-0.44)$ & $-0.0013(-0.75)$ & $0.0004(0.24)$ & $0.0029(1.27)$ & $0.0010(0.68)$ & $-0.0011(-0.55)$ \\
\hline$\beta_{5}$ & $-0.0011(-0.96)$ & $-0.0003(-0.42)$ & $-0.0017(-1.34)$ & $-0.0033(-1.97)^{*}$ & $0.0004(0.26)$ & $0.0019(0.95)$ & $-0.0003(-0.22)$ & $-0.0020(-1.06)$ \\
\hline$\beta_{6}$ & $-0.0001(-0.01)$ & $0.0008(1.15)$ & $-0.0002(-0.16)$ & $-0.0019(-1.04)$ & $-0.0001(-0.09)$ & $0.0033(1.46)$ & $0.0005(0.34)$ & $-0.0011(-0.61)$ \\
\hline Adj. $R^{2}$ & 0.55 & 0.22 & 0.56 & 0.54 & 0.58 & 0.50 & 0.53 & 0.56 \\
\hline F-Statistic & 11.60 & 4.12 & 12.38 & 10.35 & 11.75 & 9.90 & 10.94 & 10.83 \\
\hline Obs. & 6516 & 2436 & 4248 & 2412 & 2448 & 1656 & 3780 & 2736 \\
\hline
\end{tabular}

Editorial Office, Dept of Economics, Warwick University, Coventry CV4 7AL, UK 